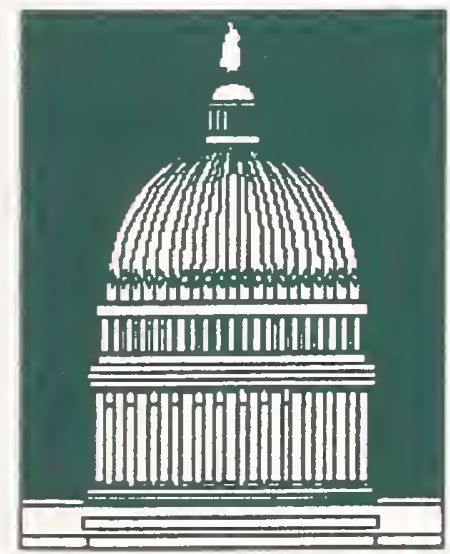

\title{
Federal Implementation Guideline for Electronic Data Interchange
}

ASC X12 003060 Transaction Set 867D

Product Transfer and Resale Report (Demand)

\section{Implementation Convention}

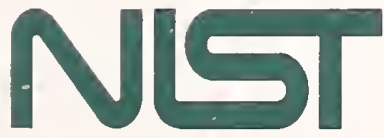

U.S. DEPARTMENT OF COMMERCE

Technology Administration

National Institute of

Standards and Technology 
$T$ he National Institute of Standards and Technology was established in 1988 by Congress to "assist industry in the development of technology ... needed to improve product quality, to modernize manufacturing processes, to ensure product reliability ... and to facilitate rapid commercialization ... of products based on new scientific discoveries."

NIST, originally founded as the National Bureau of Standards in 1901, works to strengthen U.S. industry's competitiveness; advance science and engineering; and improve public health, safety, and the environment. One of the agency's basic functions is to develop, maintain, and retain custody of the national standards of measurement, and provide the means and methods for comparing standards used in science, engineering, manufacturing, commerce, industry, and education with the standards adopted or recognized by the Federal Government.

As an agency of the U.S. Commerce Department's Technology Administration, NIST conducts basic and applied research in the physical sciences and engineering, and develops measurement techniques, test methods, standards, and related services. The Institute does generic and precompetitive work on new and advanced technologies. NIST's research facilities are located at Gaithersburg, MD 20899, and at Boulder, CO 80303. Major technical operating units and their principal activities are listed below. For more information contact the Publications and Program Inquiries Desk, 301-975-3058.

Office of the Director

- National Quality Program

- International and Academic Affairs

\section{Technology Services}

- Standards Services

- Technology Partnerships

- Measurement Services

- Technology Innovation

- Information Services

\section{Advanced Technology Program}

- Economic Assessment

- Information Technology and Applications

- Chemical and Biomedical Technology

- Materials and Manufacturing Technology

- Electronics and Photonics Technology

\section{Manufacturing Extension Partnership \\ Program \\ - Regional Prograns \\ - National Programs \\ - Program Development}

\section{Electronics and Electrical Engineering}

Laboratory

- Microclectronics

- Law Enforcement Standards

- Electricity

- Semiconductor Electronics

- Electromagnetic Fields'

- Electromagnetic Technology'

- Optoelectronics'

\section{Chemical Science and Technology}

Laboratory

- Biotechnology

- Physical and Chemical Properties ${ }^{2}$

- Analytical Chemistry

- Process Measurements

- Surface and Microanalysis Science
Physics Laboratory

- Electron and Optical Physics

- Atomic Physics

- Optical Technology

- Ionizing Radiation

- Time and Frequency'

- Quantum Physics

\section{Materials Science and Engineering} Laboratory

- Intelligent Processing of Materials

- Ceranics

- Materials Reliability

- Polymers

- Metallurgy

- NIST Center for Neutron Research

\section{Manufacturing Engineering}

Laboratory

- Precision Engineering

- Automated Production Technology

- Intelligent Systems

- Fabrication Technology

- Manufacturing Systems Integration

\section{Building and Fire Research}

Laboratory

- Structures

- Building Materials

- Building Environment

- Fire Safety Engineering

- Fire Science

Information Technology Laboratory

- Mathematical and Computational Sciences ${ }^{2}$

- Advanced Network Technologies

- Computer Security

- Information Access and User Interfaces

- High Performance Systems and Services

- Distributed Computing and Information Services

- Software Diagnostics and Conformance Testing

At Boulder, CO 80303.

Some elements at Boulder, CO. 


\section{Federal Implementation Guideline for Electronic Data Interchange}

\section{ASC X12 003060 Transaction Set 867D Product Transfer and Resale Report (Demand)}

\section{Implementation Convention}

Electronic Commerce Acquisition Program Management Office Standard Management Committee - Secretariat National Institute of Standards and Technology

Gaithersburg, MD 20899-0001

Editor: Dr. Jean-Philippe Favreau

August 1998

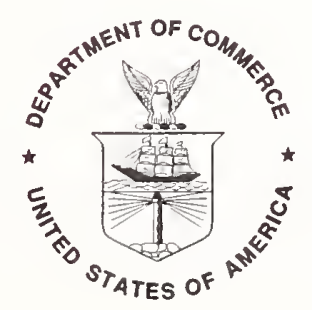

U.S. DEPARTMENT OF COMMERCE

William M. Daley, Secretary

Technology Administration

Gary R. Bachula, Acting Under Secretary for Technology

National Institute of Standards and Technology

Raymond G. Kammer, Director 


\section{Reports on Information Technology}

The National Institute of Standards and Technology (NIST)'s Information Technology Laboratory (ITL) develops standards and guidelines, provides technical assistance, and conducts research for computers and resources. As part of the overall federal effort to establish a single face to industry for conducting electronic commerce, ITL has been designated as the organization responsible for coordinating the development of Federal Implementation Conventions (ICs) for Electronic Data Interchange (EDI). ICs are defined by functional-area experts who create and select options from standard EDI Transaction Sets to yield the implementations to be used for practical EDI. These ICs are made available to federal agencies and industry by electronic means and this Special Publication Series.

National Institute of Standards and Technology Special Publication 881-75 Natl. Inst. Stand. Technol. Spec. Publ. 881-75, 42 pages (Aug. 1998) CODEN: NSPUE2

\section{U.S. GOVERNMENT PRINTING OFFICE WASHINGTON: 1998}


Functional Group ID=PT

\section{Introduction:}

This Draft Standard for Trial Use contains the format and establishes the data contents of the Product Transfer and Resale Report Transaction Set (867) for use within the context of an Electronic Data Interchange (EDI) environment. The transaction set can be used to: (1) report information about product that has been transferred from one location to another; (2) report sales of product from one or more locations to an end customer; or (3) report sales of a product from one or more locations to an end customer, and demand beyond actual sales (lost orders). Report may be issued by either buyer or seller.

\section{Notes:}

\section{Organizations use this transaction set to record demand for items that are obtained locally.}

2. Use a single occurrence of this transaction set to transmit demand transactions to one or more activities. Use one occurrence of this transaction set to transmit a single or multiple transactions.

\section{A single transaction set may contain a combination of demand transactions for standard and nonstandard material.}

4. Users operating under the Defense Logistics Management System (DLMS) must reference the Unit of Issue and Purchase Unit Conversion Table and Accounting Classification Appendix which can be found on the National Institute of Standards and Teclinology (NIST) World Wide Web site.

\section{Heading:}

\begin{tabular}{|c|c|c|c|c|c|c|c|}
\hline Must Use & $\begin{array}{l}\text { Pos. } \\
\text { No. } \\
010\end{array}$ & $\begin{array}{l}\text { Seg. } \\
\frac{\text { ID }}{\text { ST }}\end{array}$ & $\frac{\text { Name }}{\text { Transaction Set Header }}$ & $\begin{array}{l}\text { Req. } \\
\text { Des. } \\
M\end{array}$ & $\frac{\text { Max.Use }}{1}$ & $\begin{array}{c}\text { Loop } \\
\text { Repeat }\end{array}$ & $\begin{array}{l}\text { Notes and } \\
\text { Comments } \\
\end{array}$ \\
\hline Must Use & 020 & BPT & $\begin{array}{l}\text { Beginning Segment for Product Transfer and } \\
\text { Resale }\end{array}$ & M & 1 & & \\
\hline Not Used & 040 & CUR & Currency & $\mathrm{O}$ & 1 & & \\
\hline Not Used & 050 & DTM & Date/Time Reference & $\mathrm{O}$ & 10 & & \\
\hline Not Used & 060 & REF & Reference Identification & $\mathrm{O}$ & 12 & & \\
\hline Not Used & 070 & PER & Administrative Communications Contact & $\mathrm{O}$ & 3 & & \\
\hline Not Used & 075 & MEA & Measurements & $\mathrm{O}$ & 20 & & \\
\hline \multirow[t]{2}{*}{ Not Used } & 078 & PSA & Partner Share Accounting & $\mathrm{O}$ & 10 & & \\
\hline & & & LOOP ID - N1 & & & 5 & \\
\hline Must Use & 080 & N1 & Name & $\mathrm{O}$ & 1 & & \\
\hline Not Used & 090 & N2 & Additional Name Information & $\mathrm{O}$ & 2 & & \\
\hline Not Used & 100 & N3 & Address Information & $\mathrm{O}$ & 2 & & \\
\hline Not Used & 110 & N4 & Geographic Location & $\mathrm{O}$ & 1 & & \\
\hline \multirow[t]{3}{*}{ Not Used } & 120 & REF & Reference Identification & $\mathrm{O}$ & 12 & & \\
\hline & & & $\overline{\text { LOOP ID - PER }}$ & & & $>1$ & \\
\hline & 130 & PER & Administrative Communications Contact & $\mathrm{O}$ & 1 & & \\
\hline \multirow[t]{2}{*}{ Not Used } & 135 & REF & Reference Identification & $\mathrm{O}$ & $>1$ & & \\
\hline & & & LOOP ID - LM & & & $>1$ & \\
\hline Must Use & 140 & LM & Code Source Information & $\mathrm{O}$ & 1 & & \\
\hline
\end{tabular}


867D - Product Transfer and Resale Report (Demand)

$\begin{array}{lllll}\text { Must Use } & 150 & \text { LQ } & \text { Industry Code } & \text { M }\end{array}$

\section{Detail:}

\begin{tabular}{|c|c|c|c|c|c|c|c|}
\hline & $\begin{array}{l}\text { Pos. } \\
\text { No. }\end{array}$ & $\begin{array}{l}\text { Seg. } \\
\underline{\text { ID }}\end{array}$ & Name & $\begin{array}{l}\text { Req. } \\
\text { Des. }\end{array}$ & Max.Use & $\begin{array}{c}\text { Loop } \\
\text { Repeat }\end{array}$ & $\begin{array}{l}\text { Notes and } \\
\text { Comments }\end{array}$ \\
\hline & & & LOOP ID - PTD & & & $>1$ & \\
\hline \multirow[t]{2}{*}{ Must Use } & 010 & PTD & Product Transfer and Resale Detail & M & 1 & & \\
\hline & 020 & DTM & Date/Time Reference & $\mathrm{O}$ & 10 & & \\
\hline Must Use & 030 & REF & Reference Identification & $\mathrm{O}$ & 20 & & \\
\hline Not Used & 035 & PRF & Purchase Order Reference & $\mathrm{O}$ & 1 & & \\
\hline Not Used & 040 & PER & Administrative Communications Contact & $\mathrm{O}$ & 3 & & \\
\hline \multirow[t]{2}{*}{ Not Used } & 045 & MAN & Marks and Numbers & $\mathrm{O}$ & 1 & & \\
\hline & & & LOOP ID - N1 & & & 5 & \\
\hline Must Use & 050 & Nl & Name & $\mathrm{O}$ & 1 & & \\
\hline Not Used & 060 & $\mathrm{~N} 2$ & Additional Name Information & $\mathrm{O}$ & 2 & & \\
\hline Not Used & 070 & N3 & Address Information & $\mathrm{O}$ & 2 & & \\
\hline Not Used & 080 & N4 & Geographic Location & $\mathrm{O}$ & 1 & & \\
\hline Not Used & 090 & REF & Reference Identification & $\mathrm{O}$ & 20 & & \\
\hline \multirow[t]{2}{*}{ Not Used } & 100 & PER & Administrative Communications Contact & $\mathrm{O}$ & 3 & & \\
\hline & & & LOOP ID - SIl & & & $>1$ & \\
\hline Not Used & 105 & Sil & Sales ltem lnformation & $\mathrm{O}$ & 1 & & \\
\hline \multirow[t]{2}{*}{ Not Used } & 107 & N9 & Reference Identification & $\mathrm{O}$ & 1 & & \\
\hline & & & LOOP ID - QTY & & & $>1$ & \\
\hline \multirow[t]{2}{*}{ Must Use } & 110 & QTY & Quantity & $\mathrm{O}$ & 1 & & \\
\hline & 120 & LIN & Item Identification & $\mathrm{O}$ & 1 & & \\
\hline Not Used & 122 & $\mathrm{PO} 3$ & Additional ltem Detail & $\mathrm{O}$ & 25 & & \\
\hline Not Used & 125 & $\mathrm{PO} 4$ & 1tem Physical Details & $\mathrm{O}$ & 1 & & \\
\hline \multirow[t]{2}{*}{ Not Used } & 130 & UIT & Unit Detail & $\mathrm{O}$ & 12 & & \\
\hline & 140 & AMT & Monetary Amount & $\mathrm{O}$ & 12 & & \\
\hline \multirow[t]{3}{*}{ Not Used } & 141 & 1TA & Allowance, Charge or Service & $\mathrm{O}$ & 10 & & \\
\hline & 150 & PID & Product/Item Description & $\mathrm{O}$ & 200 & & \\
\hline & 160 & MEA & Measurements & $\mathrm{O}$ & 40 & & \\
\hline Not Used & 170 & PWK & Paperwork & $\mathrm{O}$ & 25 & & \\
\hline \multirow[t]{2}{*}{ Not Used } & 180 & PKG & Marking, Packaging, Loading & $\mathrm{O}$ & 25 & & \\
\hline & 190 & REF & Reference ldentification & $\mathrm{O}$ & $>1$ & & \\
\hline \multirow[t]{2}{*}{ Not Used } & 200 & PER & Administrative Communications Contact & $\mathrm{O}$ & 3 & & \\
\hline & 210 & DTM & Date/Time Reference & $\mathrm{O}$ & 10 & & \\
\hline \multirow[t]{8}{*}{ Not Used } & 220 & CUR & Currency & $\mathrm{O}$ & 1 & & \\
\hline & 230 & AT & Financial Accounting & $\mathrm{O}$ & $>1$ & & \\
\hline & 240 & DD & Demand Detail & $\mathrm{O}$ & 1 & & \\
\hline & 250 & LDT & Lead Time & $\mathrm{O}$ & 1 & & \\
\hline & & & LOOP ID - LM & & & $>1$ & \\
\hline & 260 & LM & Code Source Information & $\mathrm{O}$ & 1 & & \\
\hline & 270 & LQ & Industry Code & $\mathrm{O}$ & 100 & & \\
\hline & & & LOOP ID - LX & & & $>1$ & \\
\hline Not Used & 280 & $\mathrm{LX}$ & Assigned Number & $\mathrm{O}$ & 1 & & $\mathrm{n} 1$ \\
\hline Not Used & 290 & REF & Reference ldentification & $\mathrm{O}$ & $>1$ & & \\
\hline Not Used & 300 & DTM & Date/Time Reference & $\mathrm{O}$ & 1 & & \\
\hline
\end{tabular}


867D - Product Transfer and Resale Report (Demand)

\begin{tabular}{|c|c|c|c|c|c|c|}
\hline Not Used & 310 & N1 & Name & $\mathrm{O}$ & 1 & \\
\hline & & & LOOP ID - LM & & & $>1$ \\
\hline Not Used & 320 & LM & Code Source Information & $\mathrm{O}$ & 1 & \\
\hline Not Used & 330 & LQ & Industry Code & M & 100 & \\
\hline
\end{tabular}

\section{Summary:}

Pos. Seg.

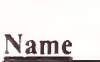

Req.

Max.Use

LOOP 1D - CTT

De

Transaction Totals

O

1

Loop Notes and

Not Used $010 \quad$ CTT

Monetary Amount

Not Used 020 AMT

Allowance, Charge or Service

$\mathrm{O}$

$\mathrm{O}$

Comments

Not Used 021 ITA

Transaction Set Trailer

M

$\mathrm{n} 2$

Must Use

$030 \quad \mathrm{SE}$

\section{Transaction Set Notes}

1. The LX loop conveys serial number, lot number, and inventory data.

2. The number of line items (CTT01) is the accumulation of the number of LIN segments. If used, hash total (CTT02) is the sum of the value of quantities (QTY02) for each QTY segment. 


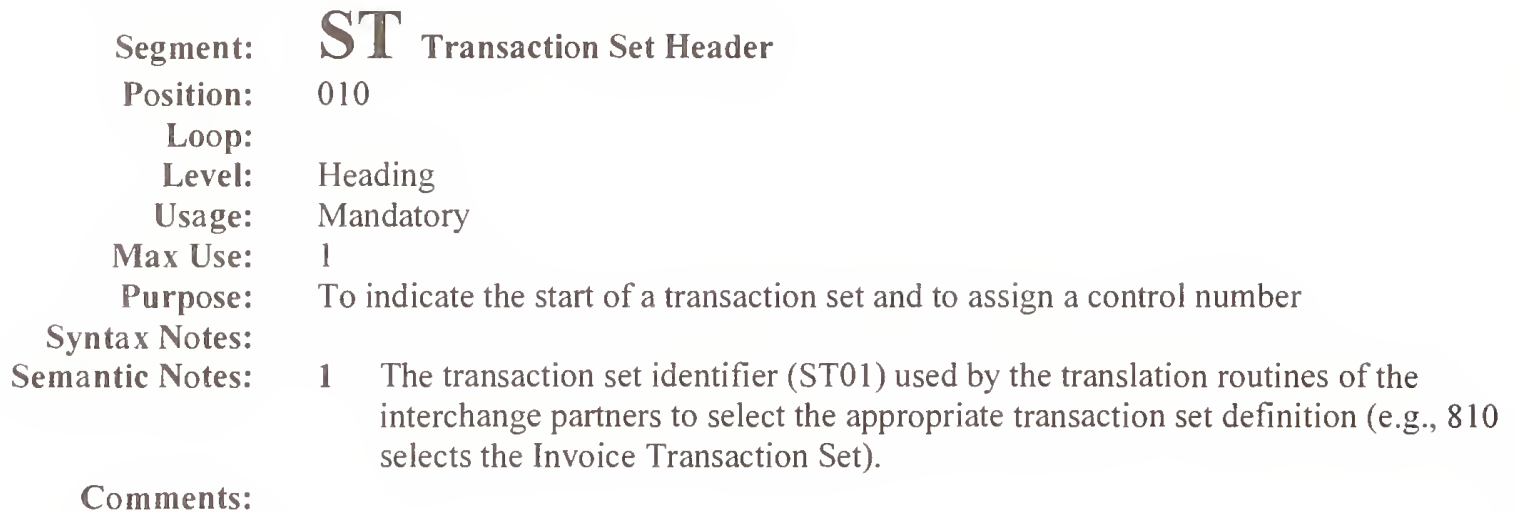

Data Element Summary

Ref. Data

Des. Element Name

Must Use $\quad \overline{\text { ST01 }} \quad \frac{143}{\text { Transaction Set Identifier Code }}$

Code uniquely identifying a Transaction Set

Attributes

M ID 3/3

867

X12.33 Product Transfer and Resale Report

Must Use ST02

329

Transaction Set Control Number

M AN 4/9

Identifying control number that must be unique within the transaction set functional group assigned by the originator for a transaction set A unique number assigned by the originator of the transaction set, or the originator's application program. 


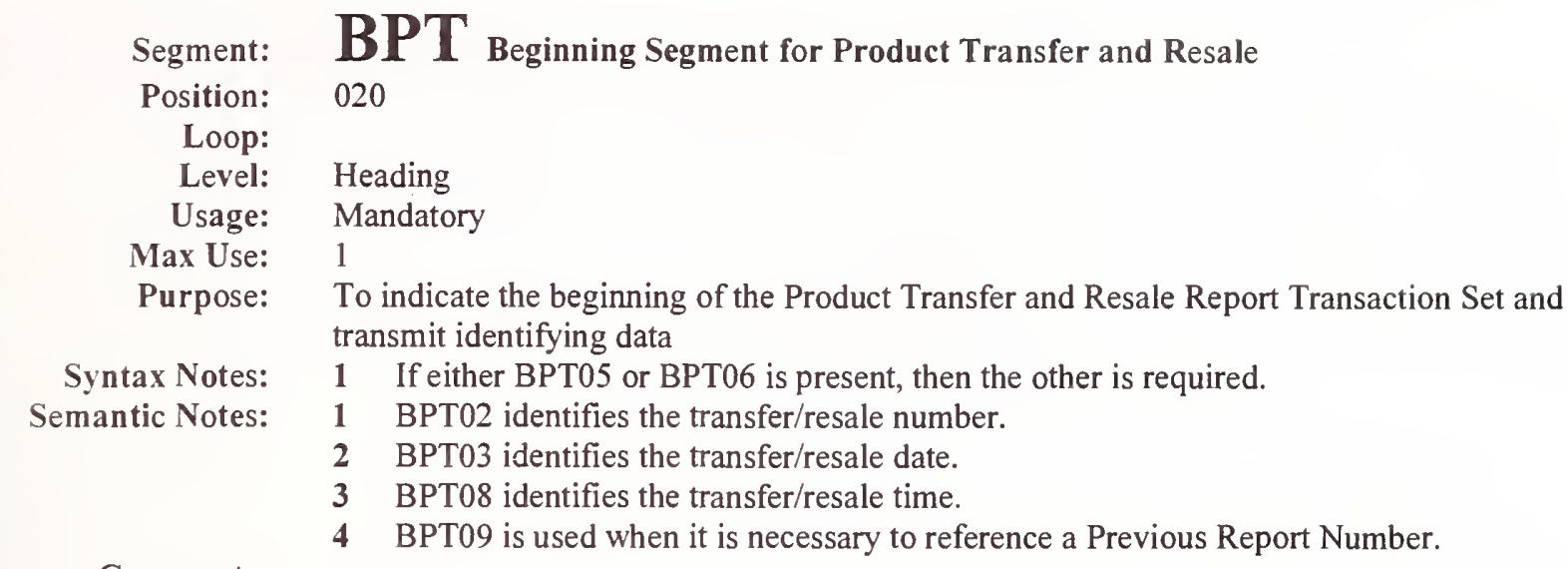

Comments:

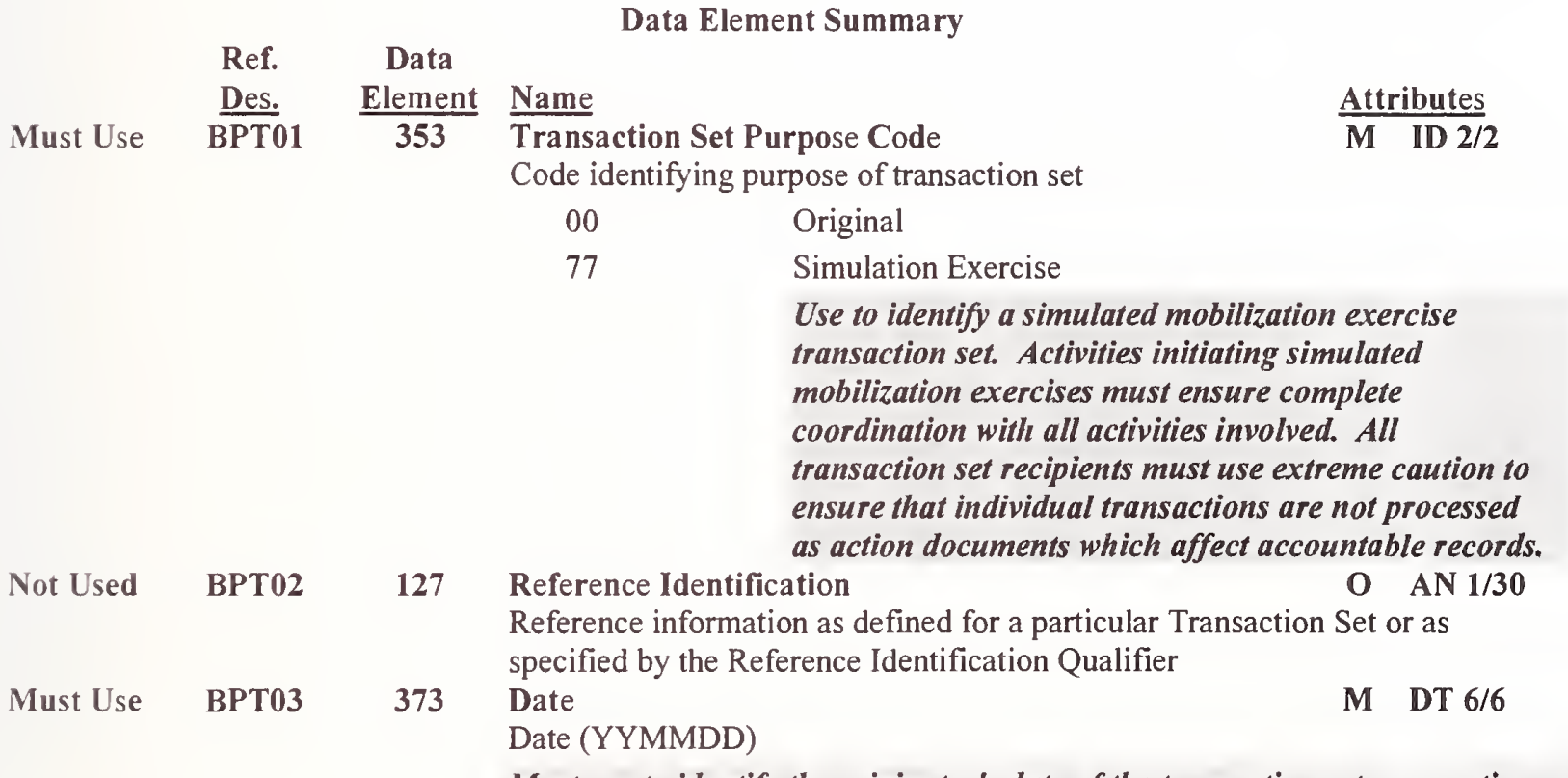

Must use to identify the originator's date of the transaction set preparation. This date corresponds to the Universal Time Coordinate (UTC).

$\begin{array}{llll}\text { Must Use } & \text { BPT04 } 755 & \begin{array}{l}\text { Report Type Code } \\ \text { Code indicating the title or contents of a document, report or supporting item }\end{array}\end{array}$

TO

Demand Report

Use to indicate that the transaction set contains demand transactions for standard or nonstandard material.

\begin{tabular}{|c|c|c|c|c|c|}
\hline Not Used & BPT05 & 648 & $\begin{array}{l}\text { Price Multiplier Qualifier } \\
\text { Code indicating the type of price multiplier }\end{array}$ & $\mathbf{X}$ & ID $3 / 3$ \\
\hline Not Used & BPT06 & 649 & $\begin{array}{l}\text { Multiplier } \\
\text { Value to be used as a multiplier to obtain a new value }\end{array}$ & $\mathbf{X}$ & R $1 / 10$ \\
\hline \multirow[t]{3}{*}{ Not Used } & ВРТ07 & 306 & $\begin{array}{l}\text { Action Code } \\
\text { Code indicating type of action }\end{array}$ & $\mathbf{O}$ & ID $1 / 2$ \\
\hline & BPT08 & 337 & Time & $\mathbf{O}$ & TM 4/8 \\
\hline & & & \multicolumn{3}{|c|}{$\begin{array}{l}\text { Time expressed in } 24 \text {-hour clock time as follows: HHMM, or HHMMSS, or } \\
\text { HHMMSSD, or HHMMSSDD, where } \mathrm{H}=\text { hours }(00-23), \mathrm{M}=\text { minutes }(00- \\
59), \mathrm{S}=\text { integer seconds }(00-59) \text { and } \mathrm{DD}=\text { decimal seconds; decimal seconds } \\
\text { are expressed as follows: } \mathrm{D}=\text { tenths }(0-9) \text { and } \mathrm{DD}=\text { hundredths }(00-99) \\
\text { 1. Express the originating activity's transaction set preparation time of in }\end{array}$} \\
\hline
\end{tabular}


867D - Product Transfer and Resale Report (Demand)

UTC.

Not Used BPT09

127

2. Express time in a four-position (HHMM) format.

Reference Identification

O AN 1/30

Reference information as defined for a particular Transaction Set or as specified by the Reference Identification Qualifier

Not Used BPT10 786 Security Level Code

O ID $2 / 2$

Code indicating the level of confidentiality assigned by the sender to the information following 


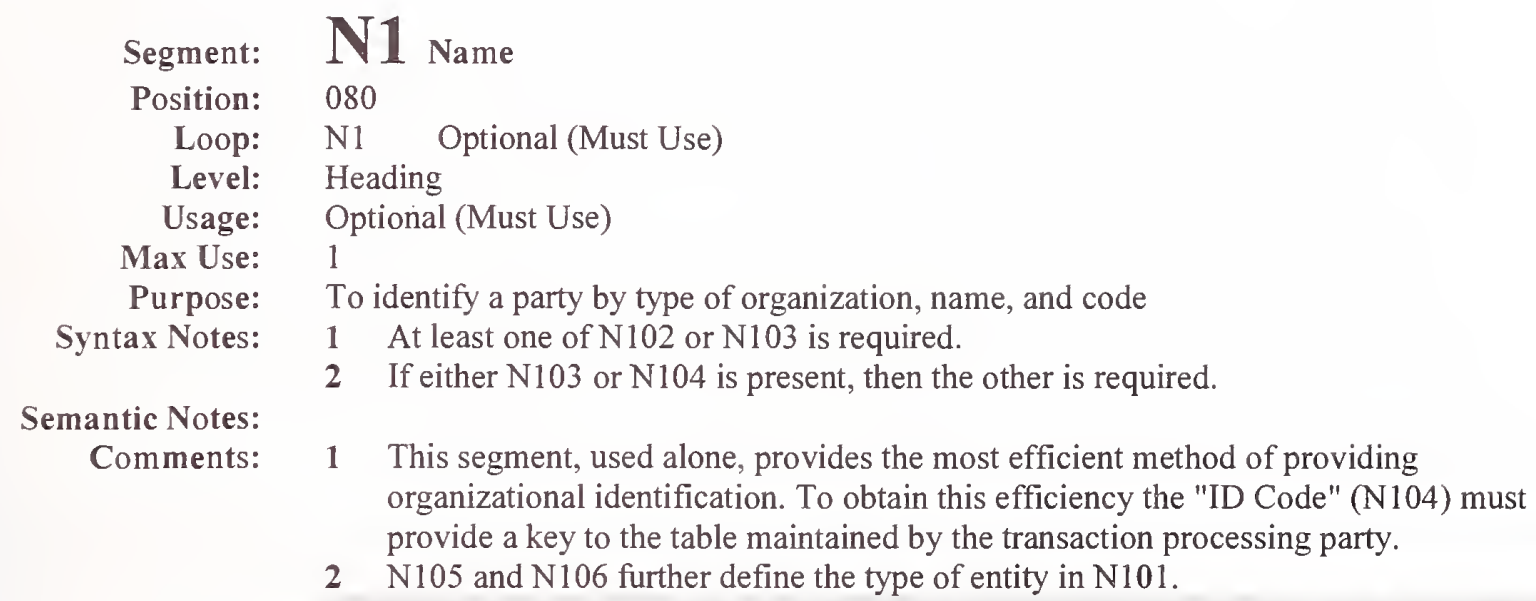

Notes: Must use this 1/N1/080 loop to identify the organization originating the transaction set.

Ref. Data

Des. Element Name

Data Element Summary

\begin{tabular}{|c|c|c|c|c|}
\hline \multirow[t]{9}{*}{ Must Use } & \multirow[t]{9}{*}{$\frac{\text { Des. }}{\text { N101 }}$} & \multirow[t]{9}{*}{$\frac{\text { Element }}{98}$} & & $\begin{array}{l}\text { Entity Identifier Code } \\
\text { Code identifying an organizational entity, a physical location, or an individual }\end{array}$ \\
\hline & & & \multicolumn{2}{|c|}{ Use only one of codes $O B, Q B$, or $S B$} \\
\hline & & & \multirow[t]{2}{*}{ OB } & Ordered By \\
\hline & & & & Use to identify the requisitioner. \\
\hline & & & QB & Purchase Service Provider \\
\hline & & & & Entity from which medical supplies may be bought \\
\hline & & & & $\begin{array}{l}\text { Use to indicate a procurement contracting office or } \\
\text { other purchasing activity. }\end{array}$ \\
\hline & & & SB & Storage Area \\
\hline & & & & Use to identify the depot or storage activity. \\
\hline Not Used & $\mathrm{N} 102$ & 93 & \multicolumn{2}{|c|}{$\begin{array}{l}\text { Name } \\
\text { Free-form name }\end{array}$} \\
\hline \multirow[t]{6}{*}{ Must Use } & N103 & 66 & \multicolumn{2}{|c|}{$\begin{array}{l}\text { Identification Code Qualifier } \quad X \quad \text { ID 1/2 } \\
\text { Code designating the system/method of code structure used for Identification } \\
\text { Code (67) }\end{array}$} \\
\hline & & & 1 & D-U-N-S Number, Dun \& Bradstreet \\
\hline & & & 9 & $\begin{array}{l}\text { D-U-N-S+4, D-U-N-S Number with Four Character } \\
\text { Suffix }\end{array}$ \\
\hline & & & 10 & $\begin{array}{l}\text { Department of Defense Activity Address Code } \\
\text { (DODAAC) }\end{array}$ \\
\hline & & & M4 & Department of Defense Routing Identifier Code (RIC) \\
\hline & & & & $\begin{array}{l}\text { An integral and predetermined participant in an } \\
\text { established logistical system performing general logistic } \\
\text { control, distribution, and storage functions }\end{array}$ \\
\hline Must Use & N104 & 67 & \multicolumn{2}{|c|}{$\begin{array}{lll}\text { Identification Code } & \text { X } & \text { AN 2/20 } \\
\text { Code identifying a party or other code } & & \end{array}$} \\
\hline Not Used & N105 & 706 & \multicolumn{2}{|c|}{$\begin{array}{lll}\text { Entity Relationship Code } & \text { O } & \text { ID } 2 / 2 \\
\text { Code describing entity relationship } & & \end{array}$} \\
\hline \multirow[t]{3}{*}{ Must Use } & N106 & 98 & \multicolumn{2}{|c|}{$\begin{array}{lc}\text { Entity Identifier Code } & \text { O ID } 2 / 2 \\
\text { Code identifying an organizational entity, a physical location, or an individual }\end{array}$} \\
\hline & & & FR & Message From \\
\hline & & & & $\begin{array}{l}\text { Must use with the appropriate } 1 / N 101 / 080 \text { code to } \\
\text { indicate that the organization cited in N104 is } \\
\text { originating the transaction set. }\end{array}$ \\
\hline
\end{tabular}




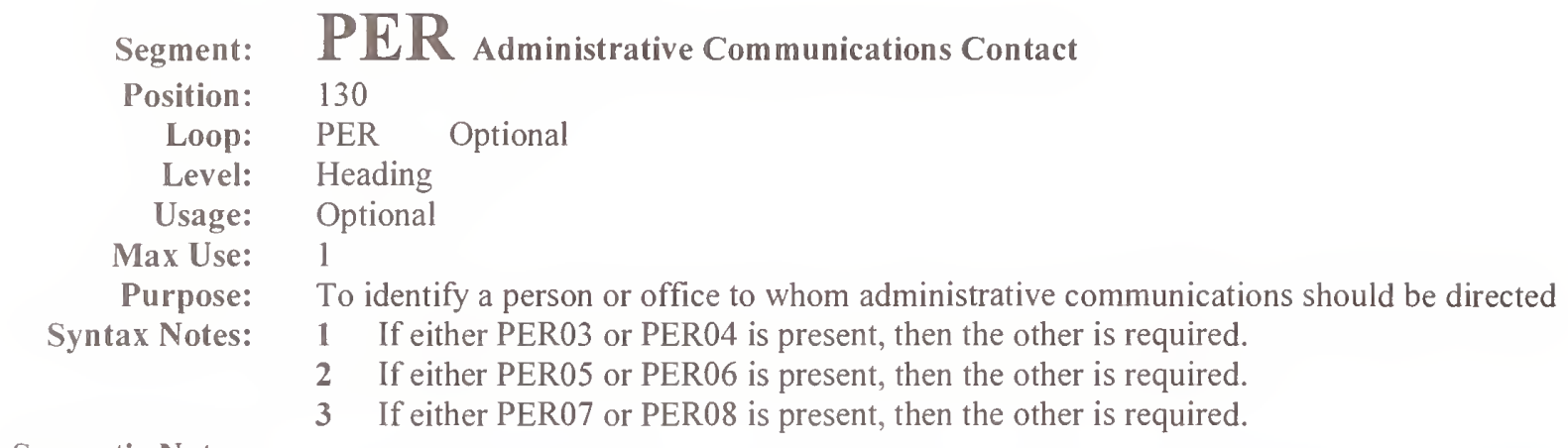

Semantic Notes:

Comments:

Notes: 1 . Use only under exceptional circumstances when requiring direct communication with the party originating the transaction set. Do not use when reversing a transaction.

2. Use multiple iterations of the 1/PER/130 loop to identify a point of contact (POC) and multiple communications numbers. When using multiple iterations to identify different comnunication numbers for a single POC, repeat the name cited in PERO2.

Ref. Data

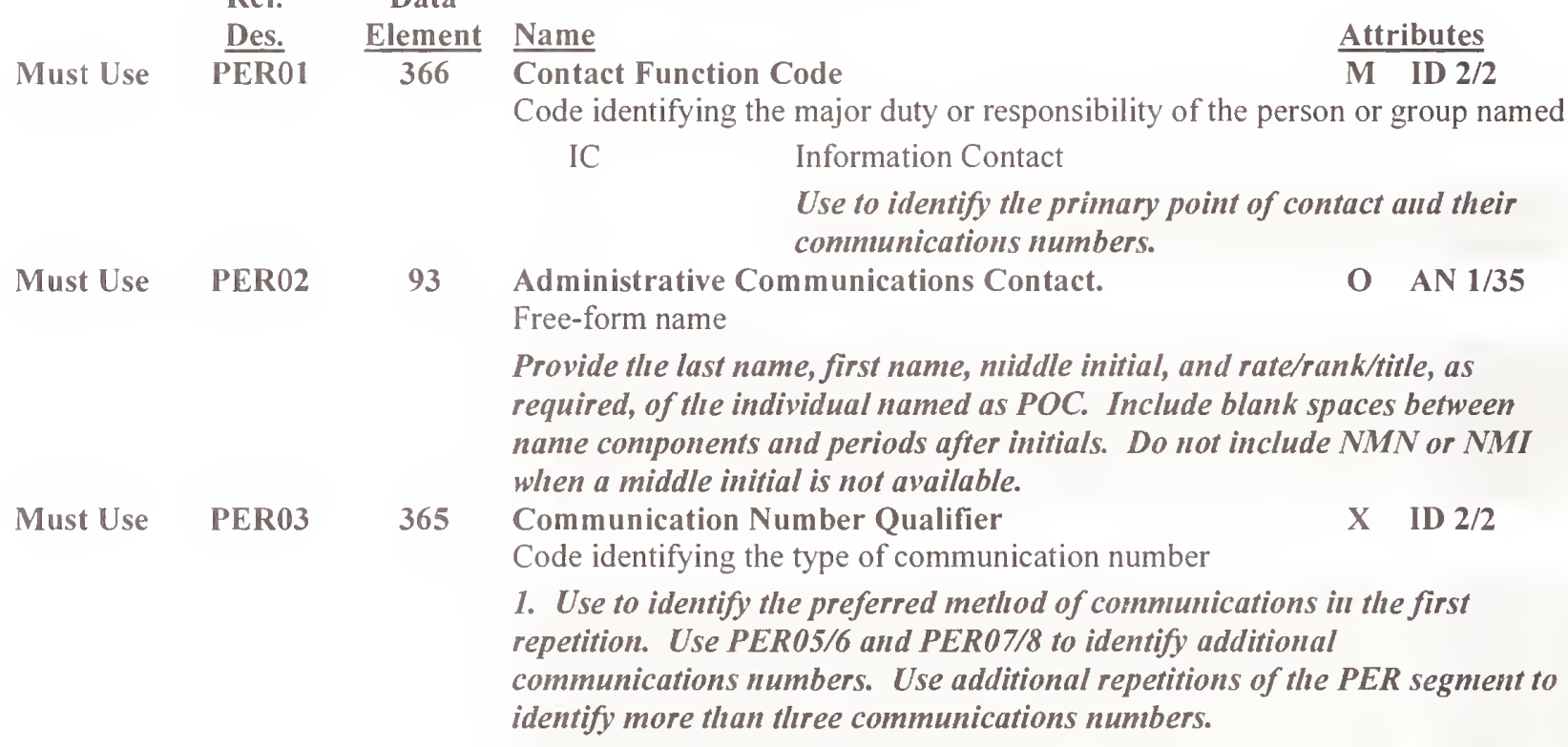

Data Element Summary

2. Do not include blank spaces, dashes or parentheses between numbers. AU Defense Switched Network successor of the Automatic Voice Network

(AUTOVON)

Use to identify the DSN telephone number.

EM Electronic Mail

FX Facsimile

Use to identify the facsimile (FAX) telephone number.

IT International Telephone

Include country and city code.

TE Telephone

Use to identify the commercial telephone number.

Include the area code and number. 
867D - Product Transfer and Resale Report (Demand)

Must Use PER04

PER05 $\begin{array}{ll}\text { TL } & \text { Telex } \\ \text { TX } & \text { TWX }\end{array}$

Communication Number

X AN 1/80

Complete communications number including country or area code when applicable

365 1. Use to identify an alternate, or secondary,

X ID $2 / 2$ communications number which can be used to contact the specified POC.

Code identifying the type of communication number

1. Use to identify an alternate, or secondary, communications number which can be used to contact the specified POC.

2. Do not include blank spaces, dashes or parentheses between numbers. $\mathrm{AU}$

Defense Switched Network

Department of Defense telecommunications system and successor of the Automatic Voice Network

(AUTOVON)

Use to identify the DSN telephone number.

\begin{tabular}{|c|c|}
\hline EM & Electronic Mail \\
\hline EX & Telephone Extension \\
\hline & $\begin{array}{l}\text { Use immediately following codes } A U, I T, \text { or } T E \text { to } \\
\text { identify the telephone extension. }\end{array}$ \\
\hline FX & Facsimile \\
\hline & Use to identify the facsimile (FAX) telephone number. \\
\hline IT & International Telephone \\
\hline & Include country and city code. \\
\hline $\mathrm{TE}$ & Telephone \\
\hline & $\begin{array}{l}\text { Use to identify the commercial telephone number. } \\
\text { Include the area code and number. }\end{array}$ \\
\hline $\mathrm{TL}$ & Telex \\
\hline TX & TWX \\
\hline
\end{tabular}

$\begin{array}{llll}\text { PER06 } 364 \text { Communication Number } & X & \text { AN 1/80 }\end{array}$

Complete communications number including country or area code when applicable

$\begin{array}{llll}\text { PER07 } 365 & \begin{array}{l}\text { Communication Number Qualifier } \\ \text { Code identifying the type of communication number }\end{array} & \text { X ID 2/2 }\end{array}$

1. Use to identify an alternate, or secondary, communications number which can be used to contact the specified POC.

2. Do not include blank spaces, dashes, or parentheses between numbers. AU Defense Switched Network

Department of Defense telecommunications system and successor of the Automatic Voice Network

(AUTOVON)

Use to identify the DSN telephone number.

EM Electronic Mail

EX Telephone Extension

Use immediately following codes $A U, I T$, or TE to identify the telephone extension.

FX Facsimile

Use to identify the facsimile (FAX) telephone number.

IT International Telephone

Include country and city code. 
867D - Product Transfer and Resale Report (Demand)

TE

Telephone

Use to identify the commercial telephone number.

TL Include the area code and number.

TX Telex

PER08

Communication Number

X AN 1/80

Complete communications number including country or area code when applicable

443 Contact Inquiry Reference

O AN $1 / 20$

Additional reference number or description to clarify a contact number Use as needed to indicate the office symbol or activity code for the identified party. 


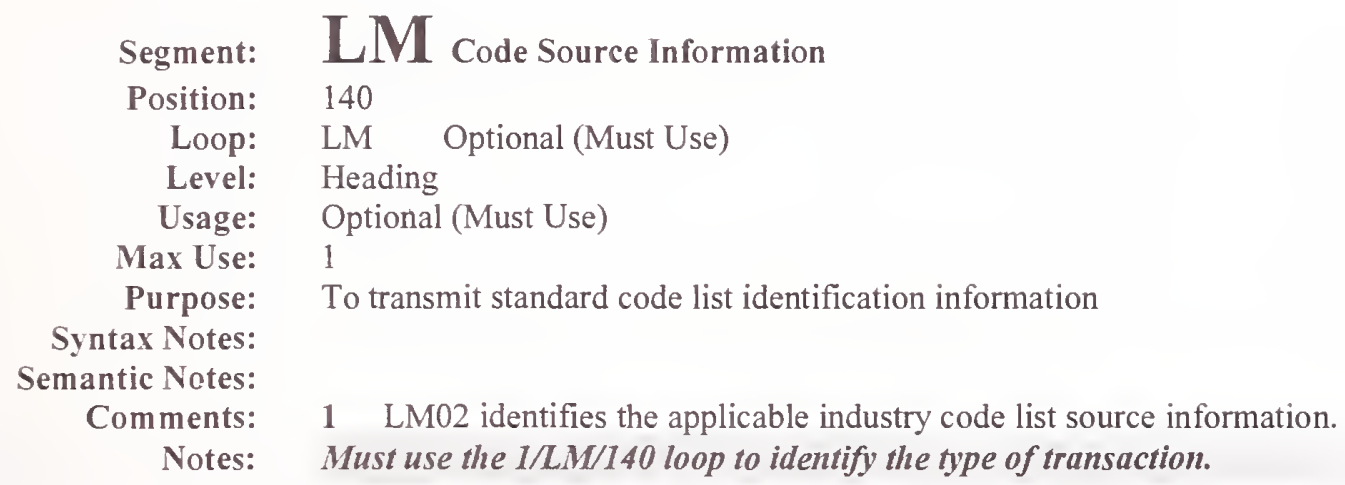

Ref. Data

\section{Data Element Summary}

\begin{tabular}{|c|c|c|c|c|}
\hline \multirow{3}{*}{ Must Use } & Des. & Element & Name & $\underline{\text { Attributes }}$ \\
\hline & LM01 & 559 & $\begin{array}{l}\text { Agency Qualifier Code } \\
\text { Code identifying the agency assigning the code values }\end{array}$ & M ID 2/2 \\
\hline & & & DF $\quad$ Department of Defense (DoD) & \\
\hline Not Used & LM02 & 822 & $\begin{array}{l}\text { Source Subqualifier } \\
\text { A reference that indicates the table or text maintained } b\end{array}$ & $\begin{array}{c}\text { O AN 1/15 } \\
\text { Source Qualifie }\end{array}$ \\
\hline
\end{tabular}


867D - Product Transfer and Resale Report (Demand)

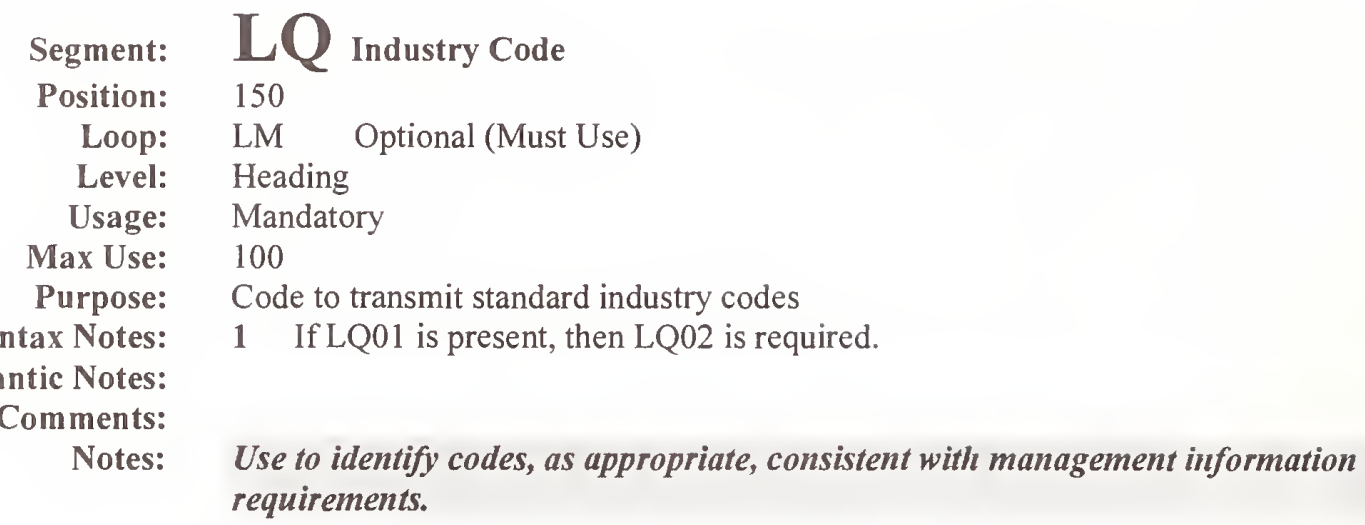

Ref. Data

Data Element Summary

\begin{tabular}{|c|c|c|c|c|c|c|}
\hline \multirow{3}{*}{ Must Use } & \multirow{3}{*}{$\frac{\text { Des. }}{\text { LQ01 }}$} & \multirow{3}{*}{$\frac{\text { Element }}{1270}$} & \multirow{2}{*}{\multicolumn{2}{|c|}{$\begin{array}{l}\text { Name } \\
\text { Code List Qualifier Code } \\
\text { Code identifying a specific industry code list }\end{array}$}} & \multicolumn{2}{|c|}{$\underline{\text { Attributes }}$} \\
\hline & & & & & O & ID $1 / 3$ \\
\hline & & & 0 & $\begin{array}{l}\text { Document Identification Code } \\
\text { Codes that subclassify a transaction }\end{array}$ & & \\
\hline Must Use & LQ02 & 1271 & $\begin{array}{l}\text { Indus } \\
\text { Code } \mathrm{i}\end{array}$ & de from a specific industry code list & $\mathbf{X}$ & AN $1 / 30$ \\
\hline
\end{tabular}




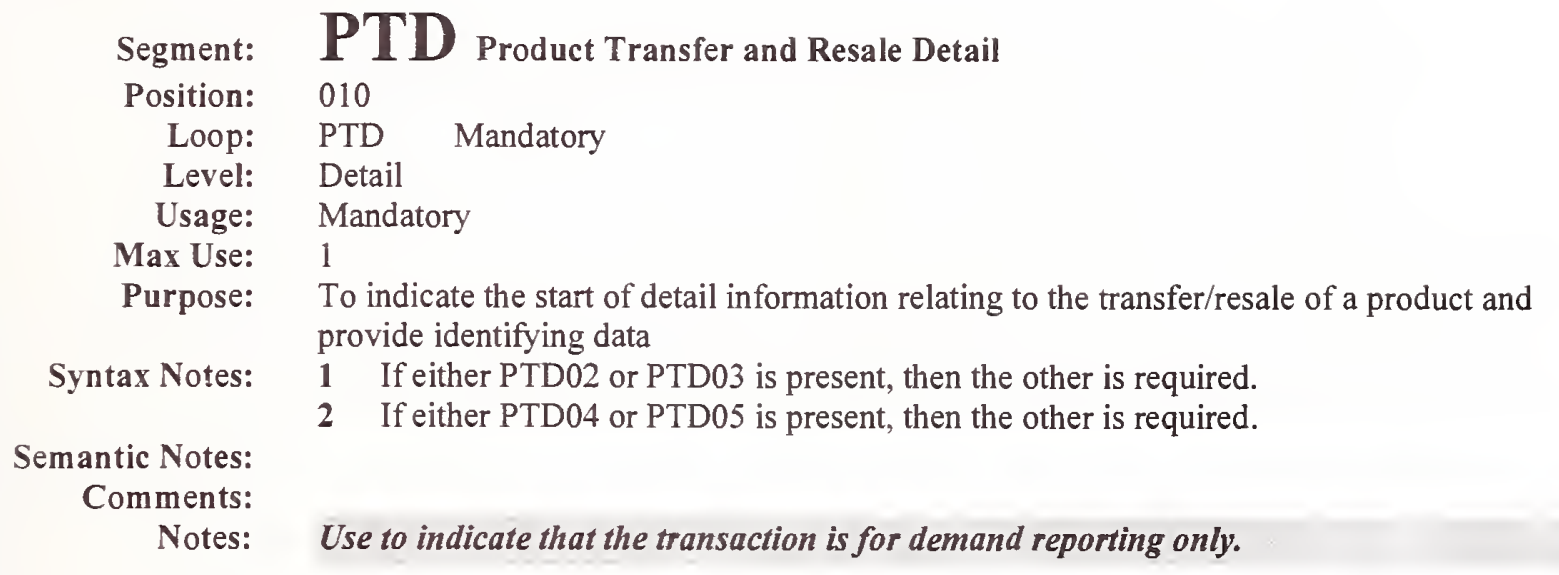

Ref. Data

Data Element Summary

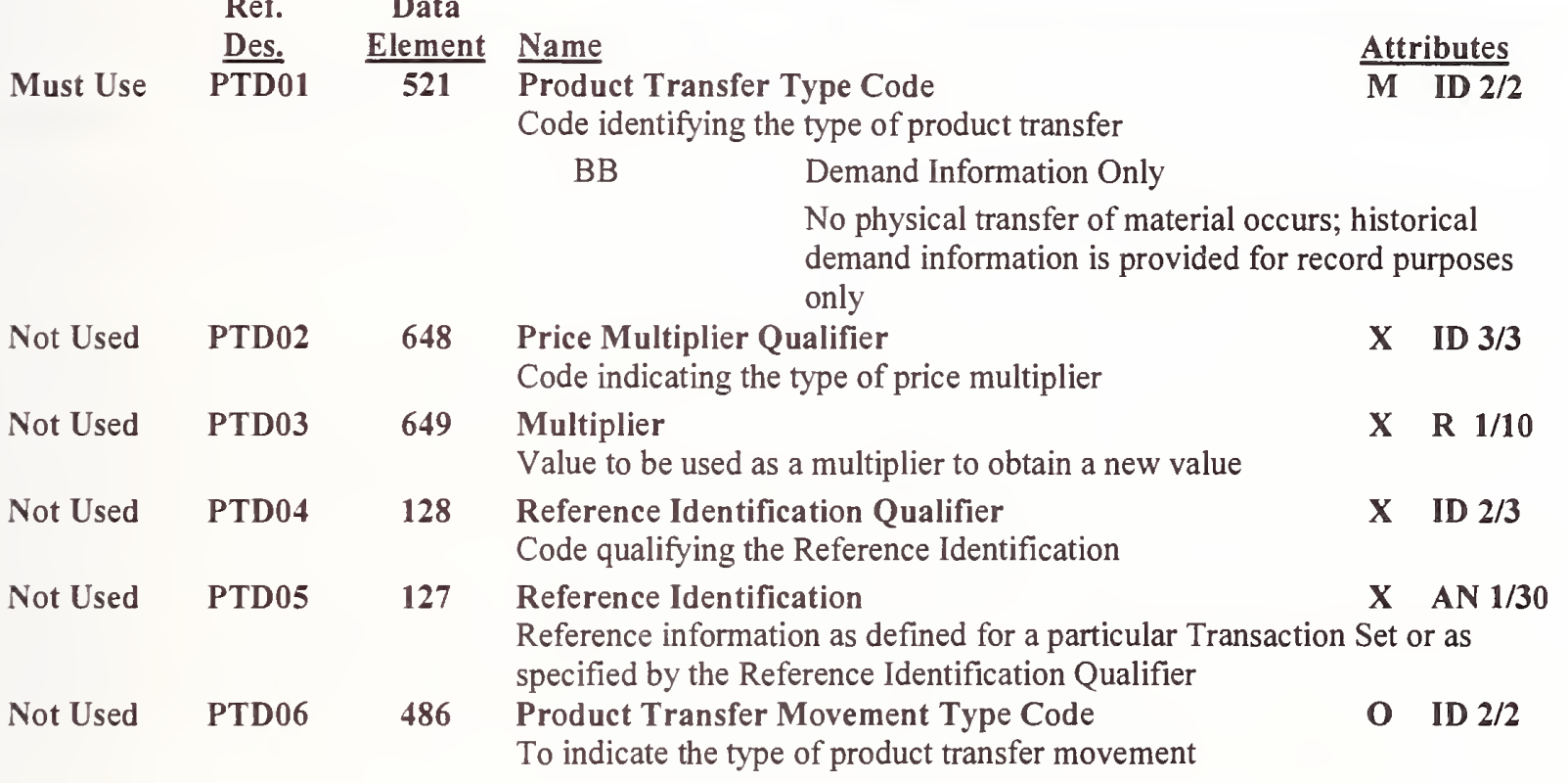




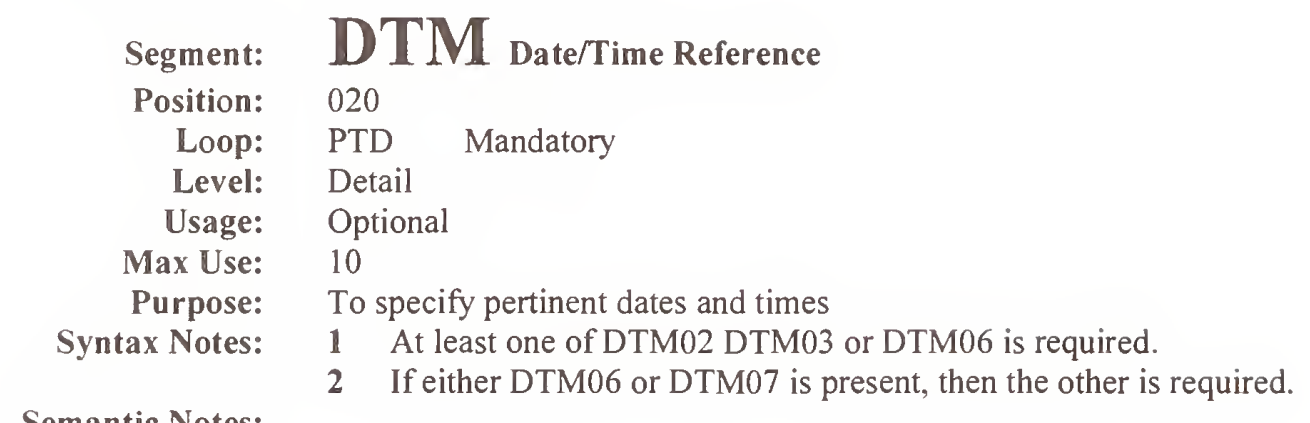

Semantic Notes:

Comments:

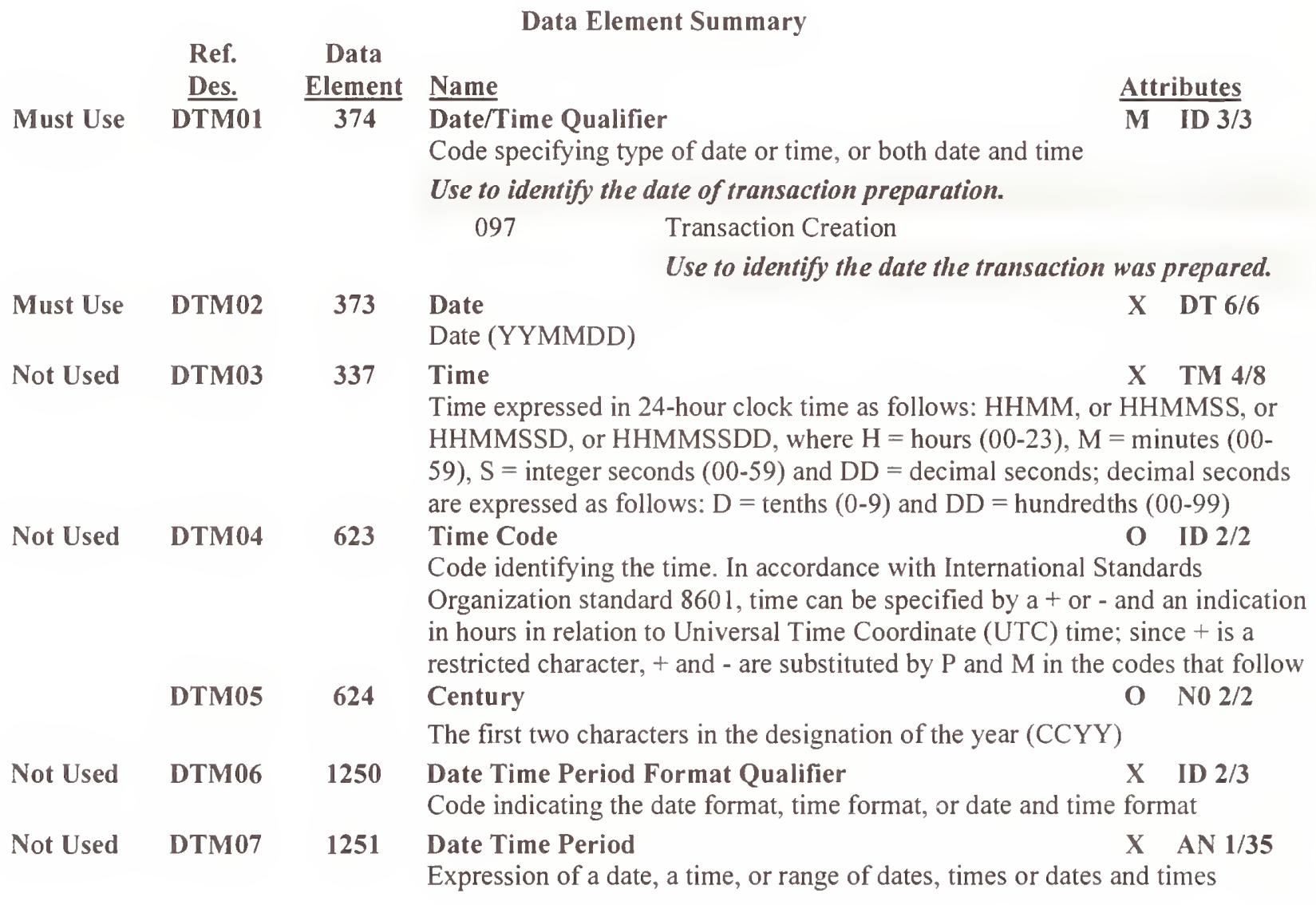




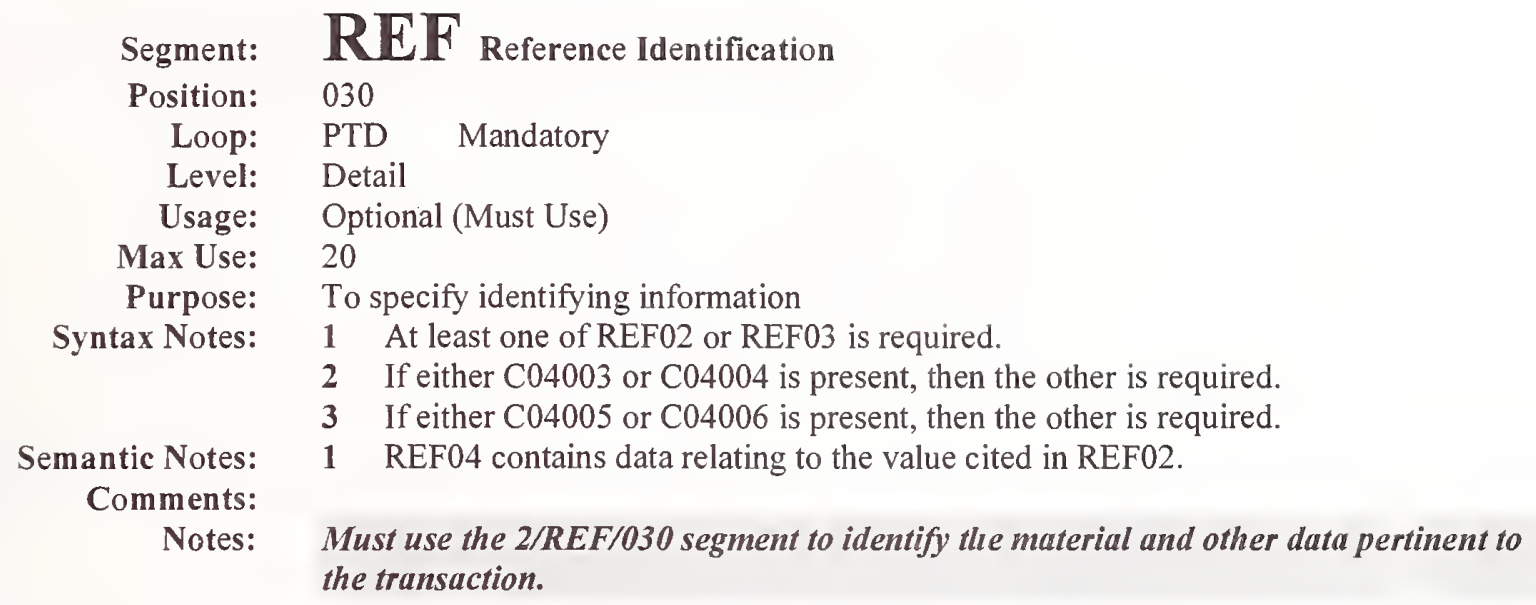


867D - Product Transfer and Resale Report (Demand)

A free-form description to clarify the related data elements and their content Use with REF01 code WL to provide a description of the material.

REF04 C040 Reference Identifier O

To identify one or more reference numbers or identification numbers as specified by the Reference Qualifier

$\begin{array}{lllll}\text { Must Use } & \text { C04001 } & 128 & \begin{array}{l}\text { Reference Identification Qualifier } \\ \text { Code qualifying the Reference Identification }\end{array} & \text { M }\end{array}$ ID 2/3

W7

Commercial and Government Entity (CAGE) Code

Code that identifies a commercial contractor authorized to do business with the U.S. Government Use with REFO1 code MF to uniquely identify the

W8 manufacturer's part number.

Differentiates between partial actions taken on the original transaction

Use in conjunction with REF01 code TN to identify the transaction number suffix.

\begin{tabular}{|c|c|c|c|c|c|}
\hline Must Use & C04002 & 127 & Reference Identification & & AN $1 / 30$ \\
\hline & & & $\begin{array}{l}\text { Reference information as defined for a particular Transaction } \\
\text { specified by the Reference Identification Qualifier }\end{array}$ & Set & \\
\hline Not Used & $\mathrm{C} 04003$ & 128 & $\begin{array}{l}\text { Reference Identification Qualifier } \\
\text { Code qualifying the Reference Identification }\end{array}$ & $\mathbf{X}$ & ID $2 / 3$ \\
\hline Not Used & C04004 & 127 & Reference Identification & $\mathbf{X}$ & AN $1 / 30$ \\
\hline & & & $\begin{array}{l}\text { Reference information as defined for a particular Transaction } \\
\text { specified by the Reference Identification Qualifier }\end{array}$ & & r as \\
\hline Not Used & C04005 & 128 & $\begin{array}{l}\text { Reference Identification Qualifier } \\
\text { Code qualifying the Reference Identification }\end{array}$ & $\mathbf{X}$ & ID $2 / 3$ \\
\hline Not Used & C04006 & 127 & Reference Identification & $\mathbf{X}$ & AN $1 / 30$ \\
\hline & & & $\begin{array}{l}\text { Reference information as defined for a particular Transaction } \\
\text { specified by the Reference Identification Qualifier }\end{array}$ & & $\mathrm{r}$ as \\
\hline
\end{tabular}


9

10

33

M4

D-U-N-S+4, D-U-N-S Number with Four Character Suffix

Department of Defense Activity Address Code (DODAAC)

Commercial and Government Entity (CAGE)

Use when the activity is a contractor not assigned a DoDAAC.

Department of Defense Routing Identifier Code (RIC)

An integral and predetermined participant in an established logistical system performing general logistic control, distribution, and storage functions

N104

$$
67
$$

Identification Code

Code identifying a party or other code

Do not use with code $Z E$.

Not Used

N105

706

N106
Entity Relationship Code

Code describing entity relationship

Entity Identifier Code

O ID $2 / 2$

O ID $2 / 2$

$\mathrm{X}$ AN 2/20

Code identifying an organizational entity, a physical location, or an individual

TO Message To

Must use with 2/N101/050 code Z4 to indicate the organization cited in $N 104$ is receiving the transaction. 


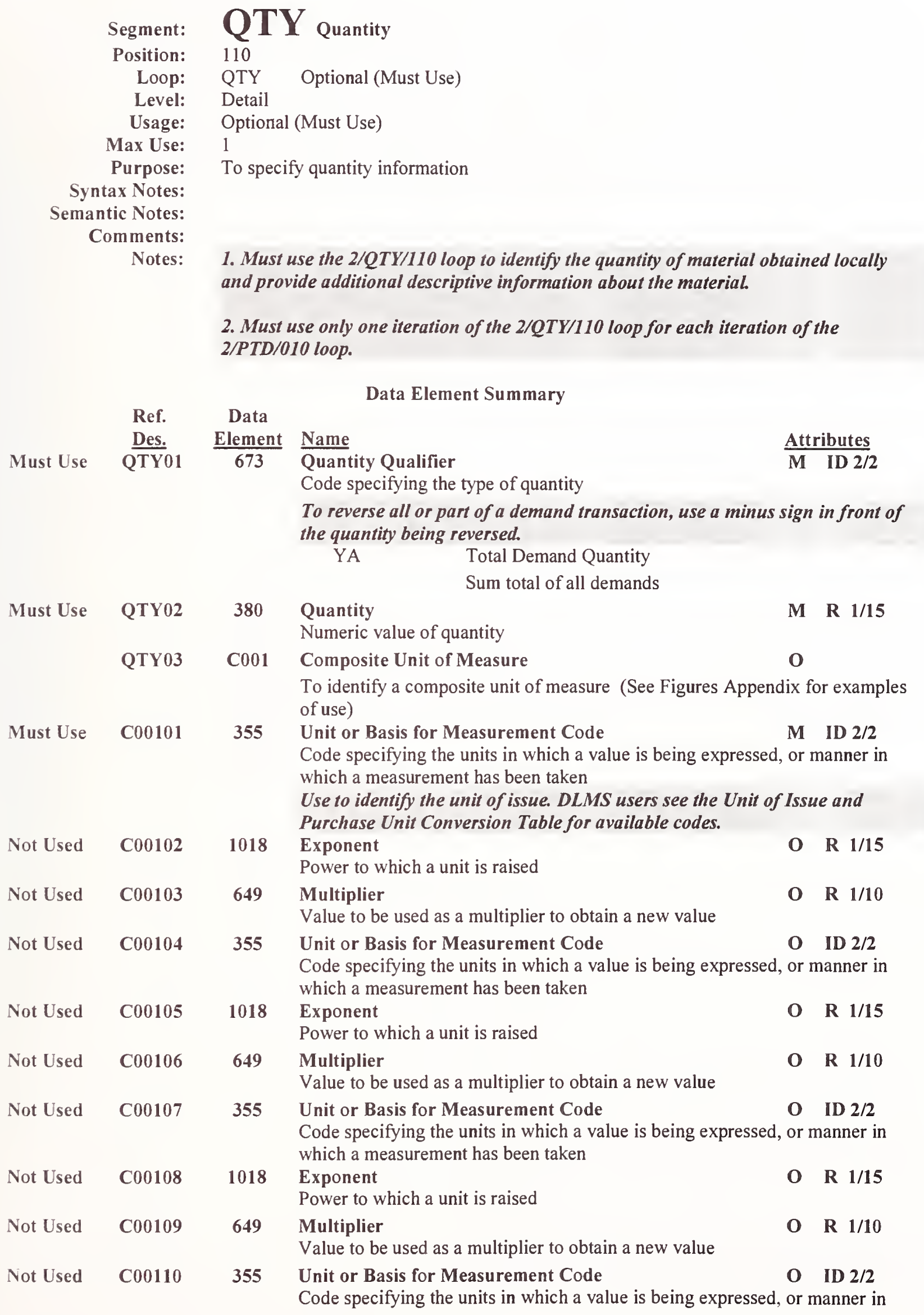


867D - Product Transfer and Resale Report (Demand)

\begin{tabular}{|c|c|c|c|c|c|}
\hline Not Used & C00111 & 1018 & $\begin{array}{l}\text { which a measurement has been taken } \\
\text { Exponent } \\
\text { Power to which a unit is raised }\end{array}$ & O & R $1 / 15$ \\
\hline Not Used & $\mathrm{C} 00112$ & 649 & $\begin{array}{l}\text { Multiplier } \\
\text { Value to be used as a multiplier to obtain a new value }\end{array}$ & $\mathbf{O}$ & R $1 / 10$ \\
\hline Not Used & $\mathrm{C} 00113$ & 355 & $\begin{array}{l}\text { Unit or Basis for Measurement Code } \\
\text { Code specifying the units in which a value is being expressed, } \\
\text { which a measurement has been taken }\end{array}$ & & $\begin{array}{l}\text { ID } 2 / 2 \\
\text { inner in }\end{array}$ \\
\hline Not Used & C00114 & 1018 & $\begin{array}{l}\text { Exponent } \\
\text { Power to which a unit is raised }\end{array}$ & $\mathbf{O}$ & $1 / 15$ \\
\hline Not Used & C00115 & 649 & $\begin{array}{l}\text { Multiplier } \\
\text { Value to be used as a multiplier to obtain a new value }\end{array}$ & $\mathbf{O}$ & $1 / 10$ \\
\hline
\end{tabular}


Semantic Notes:

Comments:

Notes:

Ref.

Not Used

$\underline{\text { Des. }}$

LIN01

Must Use LIN02

\section{LIN Item Identification}

120

QTY Optional (Must Use)

Detail

Optional

1

To specify basic item identification data

1 If either LIN04 or LIN05 is present, then the other is required.

2 If either LIN06 or LIN07 is present, then the other is required.

3 If either LIN08 or LIN09 is present, then the other is required.

4 If either LIN10 or LIN11 is present, then the other is required.

5 If either LIN12 or LIN13 is present, then the other is required.

6 If either LIN14 or LIN15 is present, then the other is required.

7 If either LIN16 or LIN17 is present, then the other is required.

8 If either LIN18 or LIN19 is present, then the other is required.

9 If either LIN20 or LIN21 is present, then the other is required.

10 If either LIN22 or LIN23 is present, then the other is required.

11 If either LIN24 or LIN25 is present, then the other is required.

12 If either LIN26 or LIN27 is present, then the other is required.

13 If either LIN28 or LIN29 is present, then the other is required.

14 If either LIN30 or LIN31 is present, then the other is required.

1 LIN01 is the line item identification

1 See the Data Dictionary for a complete list of IDs.

2 LIN02 through LIN3 1 provide for fifteen different product/service IDs for each item.

For example: Case, Color, Drawing No., U.P.C. No., ISBN No., Model No., or SKU.

1. Use only to provide a detailed description of the nonstandard material, identified in

2/REF/030. Use witl the 2/PID/150, 2/MEA/160, 2/REF/190, and 2/DTM/210

segments, and the 2/N1/050 loop to fully identify the material.

2. Use data element 235/234 pairs to identify data pertinent to the transaction. Present the information in any sequential order. Unless otherwise specified, the multiple codes listed for a single qualifier data element identify the range of possible data requirements. When needed, use the next available combination of data element 235/234 pairs to provide the necessary data.

Data Element Summary

Data

Element Name

350 Assigned Identification $\quad$ O AN 1/20

Attributes

Alphanumeric characters assigned for differentiation within a transaction set

235 Product/Service ID Qualifier

M ID $2 / 2$

Code identifying the type/source of the descriptive number used in Product/Service ID (234)

A3

Locally Assigned Control Number

Item identifier is a locally assigned control number used to catalog and manage material

Use to identify the locally assigned number under which the nonstandard material is managed.

AB Assembly

Use to identify the assembly associated with the material.

CL Color

$\mathrm{CN}$ Commodity Name

Use to identify the nomenclature of the nonstandard material.

DR Drawing Revision Number 
Product identification number

Use to identify the equipnient identification code associated of the material.

F1

F2

F3

F4

F7

GS

$\mathrm{MN}$

MS

PR

PT

PW

SN

VS
Catalog Number

Item identifier specifies a manufacturer's catalog that applies to an item

Use to identify the manufacturer's catalog which references the nonstandard material. Cite the effective catalog publication date, if applicable, in the 2/DTM/210 segment.

Technical Order Number

Item identifier specifies a technical order that applies to an item

Technical Manual Number

Item identifier specifies the technical manual listing the item

Series Identifier

An identification of equipments having the same basic design but not necessarily identical configurations (within the equipment model)

Use to cite the manufacturer's series number of the nonstandard naterial.

End-Item Description

Item identifier describes an end-item associated with the use of the required material

Use to identify the applicable end item which applies to nonstandard material. Description nay include

NSN or nomenclature.

General Specification Number

Use to indicate a specification number, other than a Military Specification (MILSPEC), associated with the nonstandard nllaterial.

Model Number

Use to identify the manufacturer's model number of the nonstandard material.

Military Specification (MILSPEC) Number

Process Number

Use to identify a general operating specification which cannot be identified by use of the $2 / M E A / 160$ segment. For example, the MEA use is primarily to identify plysical sizes and dimensions of nonstandard material. Code PR's use is to indicate specifications similar to output rated wattage and liorsepower. Print or Drawing

Use to identify the applicable drawing numbers for the nonstandard material.

Part Drawing

Use to identify the applicable figure numbers for the nonstandard material.

Serial Number

Use to identify the manufacturer's serial number assigned to the material.

Vendor's Supplemental Item Number

Use to identify the piece number of the material. 


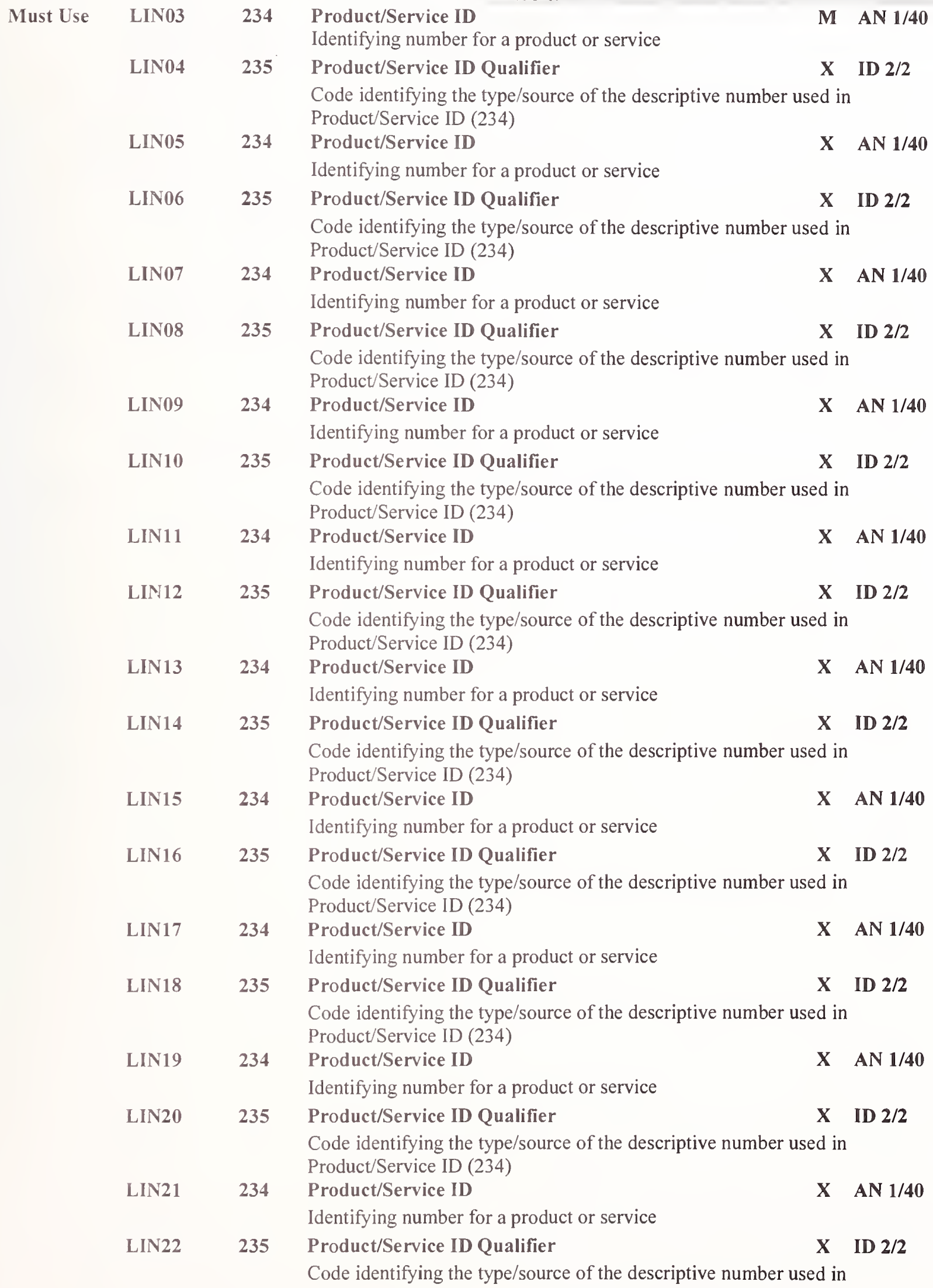


Product/Service ID (234)

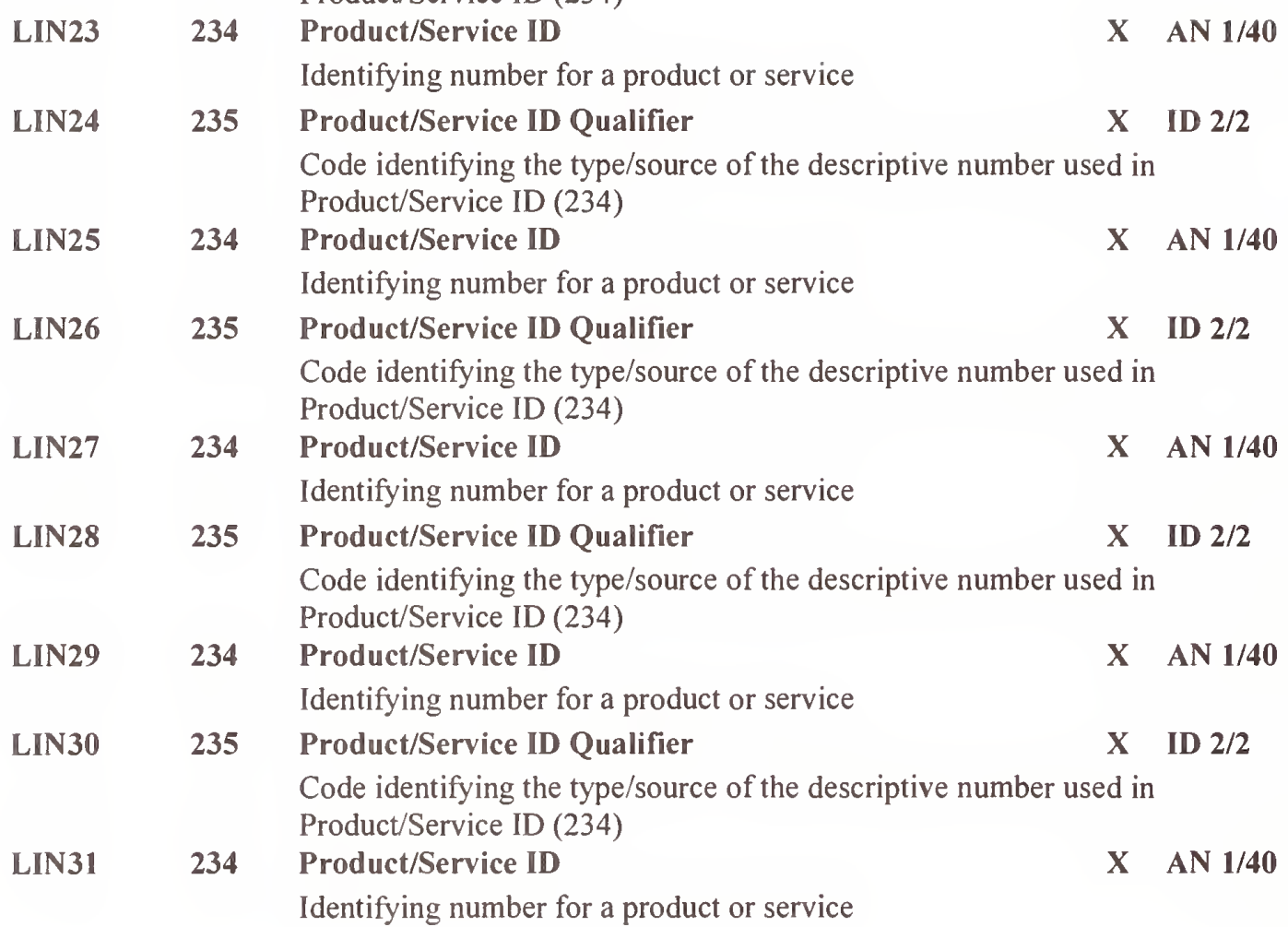




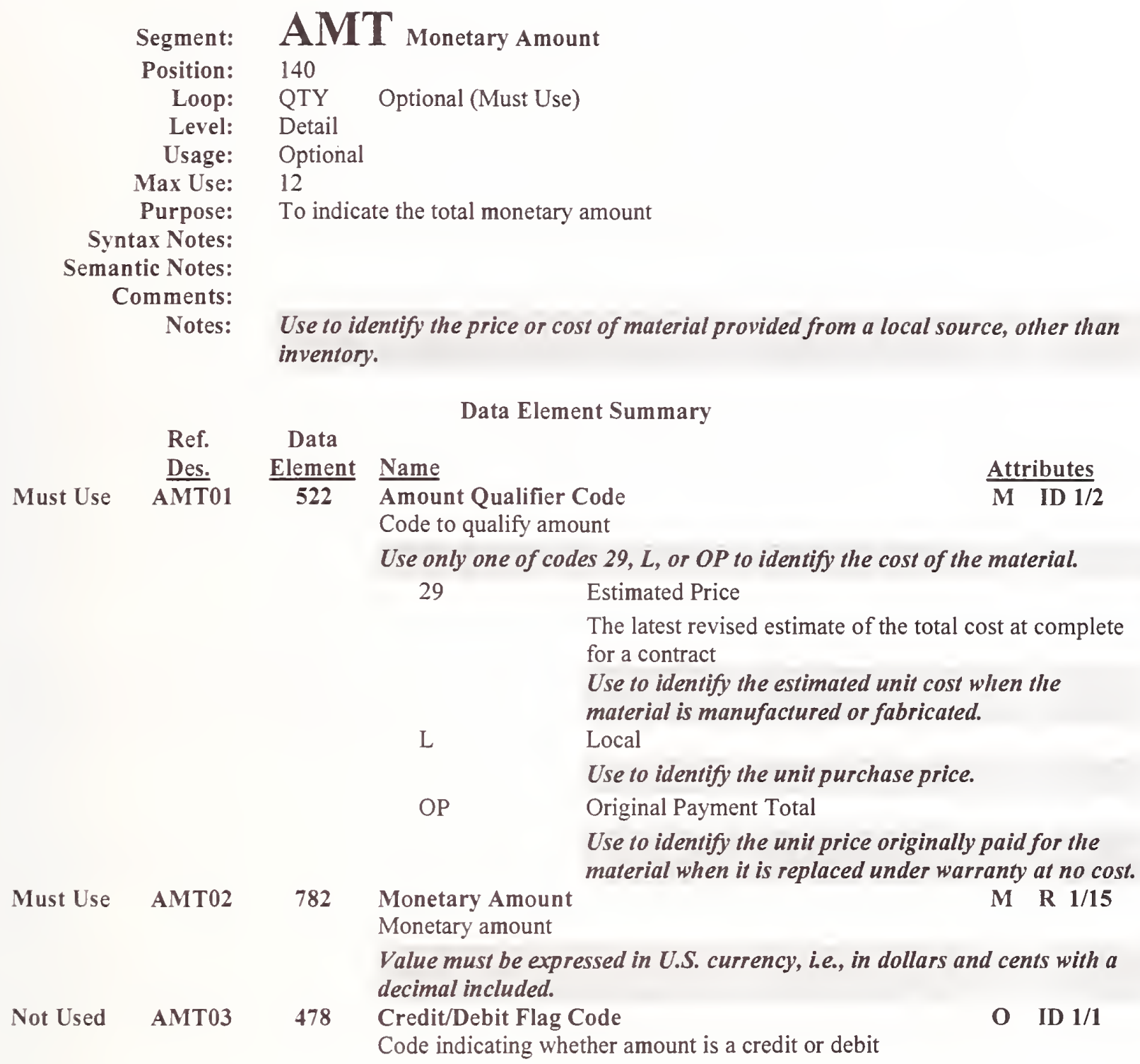

Notes: Use to identify the price or cost of material provided from a local source, other than inventory.

Ref. Data

Des. Element Name

Must Use AMT01 522

Amount Qualifier Code

$\underline{\text { Attributes }}$

Code to qualify amount

M ID $1 / 2$

Use only one of codes 29, L, or OP to identify the cost of the material. 29 Estimated Price

The latest revised estimate of the total cost at complete for a contract Use to identify the estimated unit cost when the

$\mathrm{L}$ material is manufactured or fabricated.

Use to identify the unit purchase price.

OP Original Payment Total

Use to identify the unit price originally paid for the

Must Use AMT02 782 Monetary Amount material when it is replaced under warranty at no cost.

Monetary amount

M R 1/15

Value must be expressed in U.S. currency, i.e., in dollars and cents with a decimal included.

Not Used

AMT03 478 Credit/Debit Flag Code

Code indicating whether amount is a credit or debit

O ID $1 / 1$ 


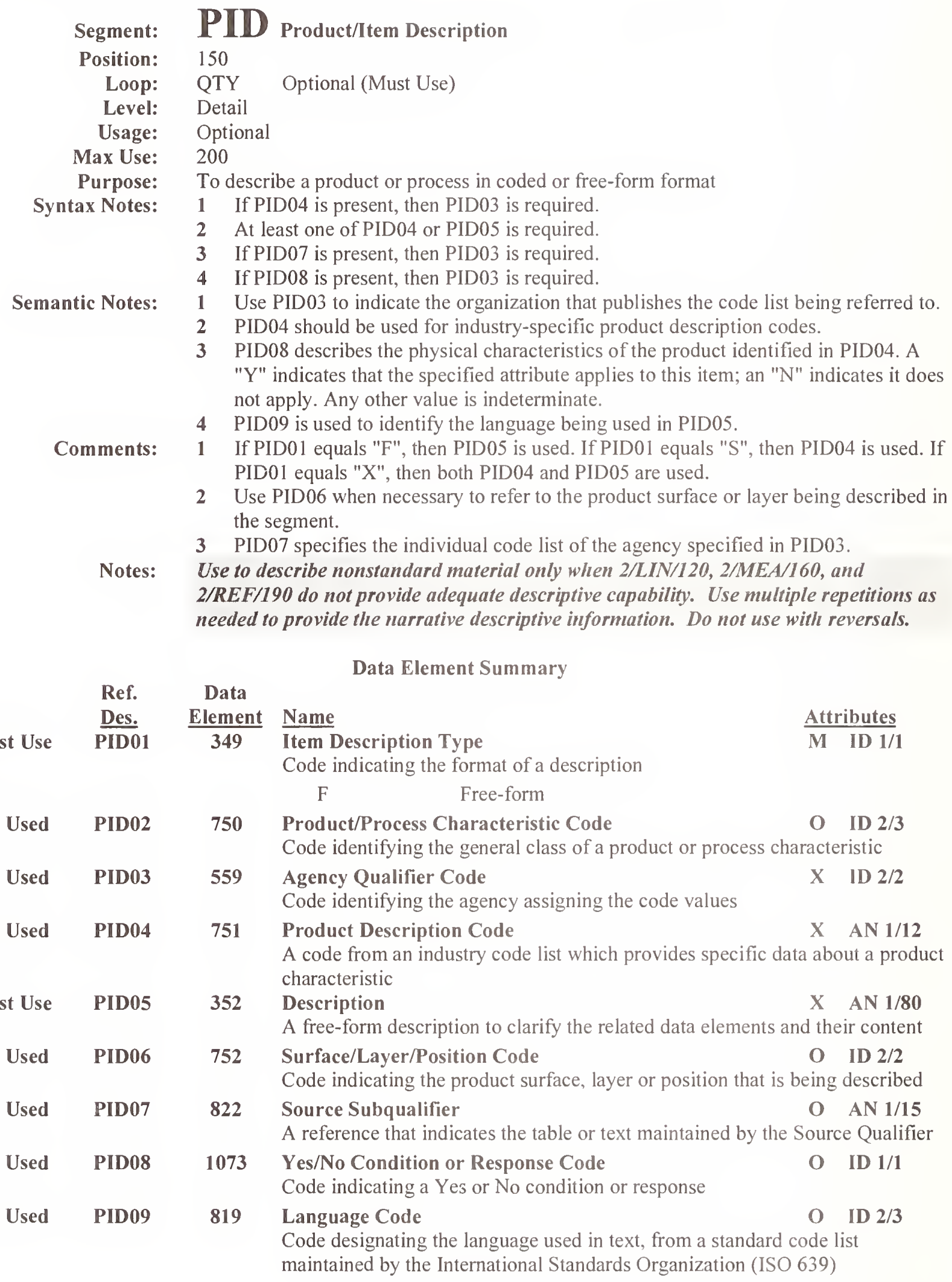




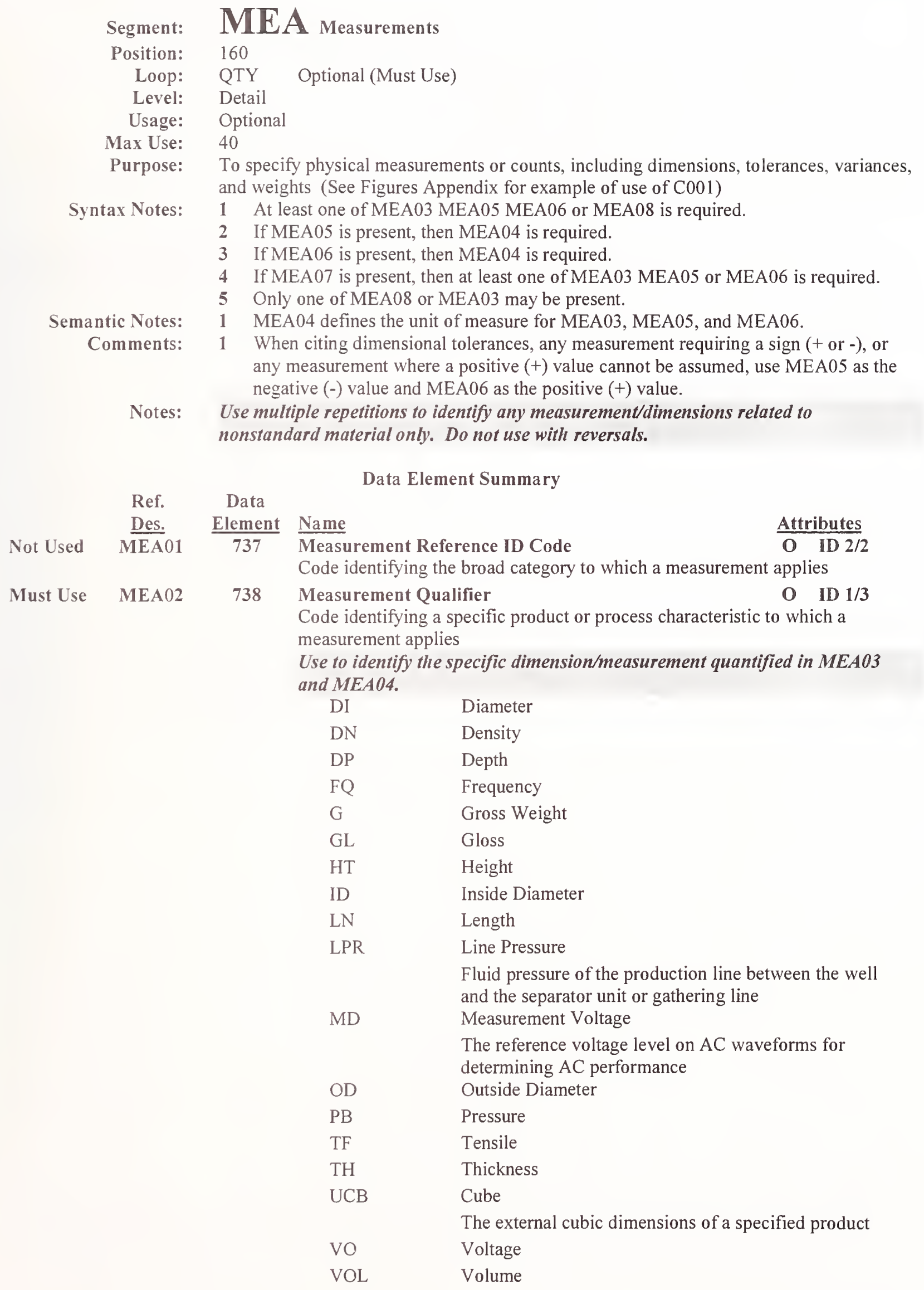




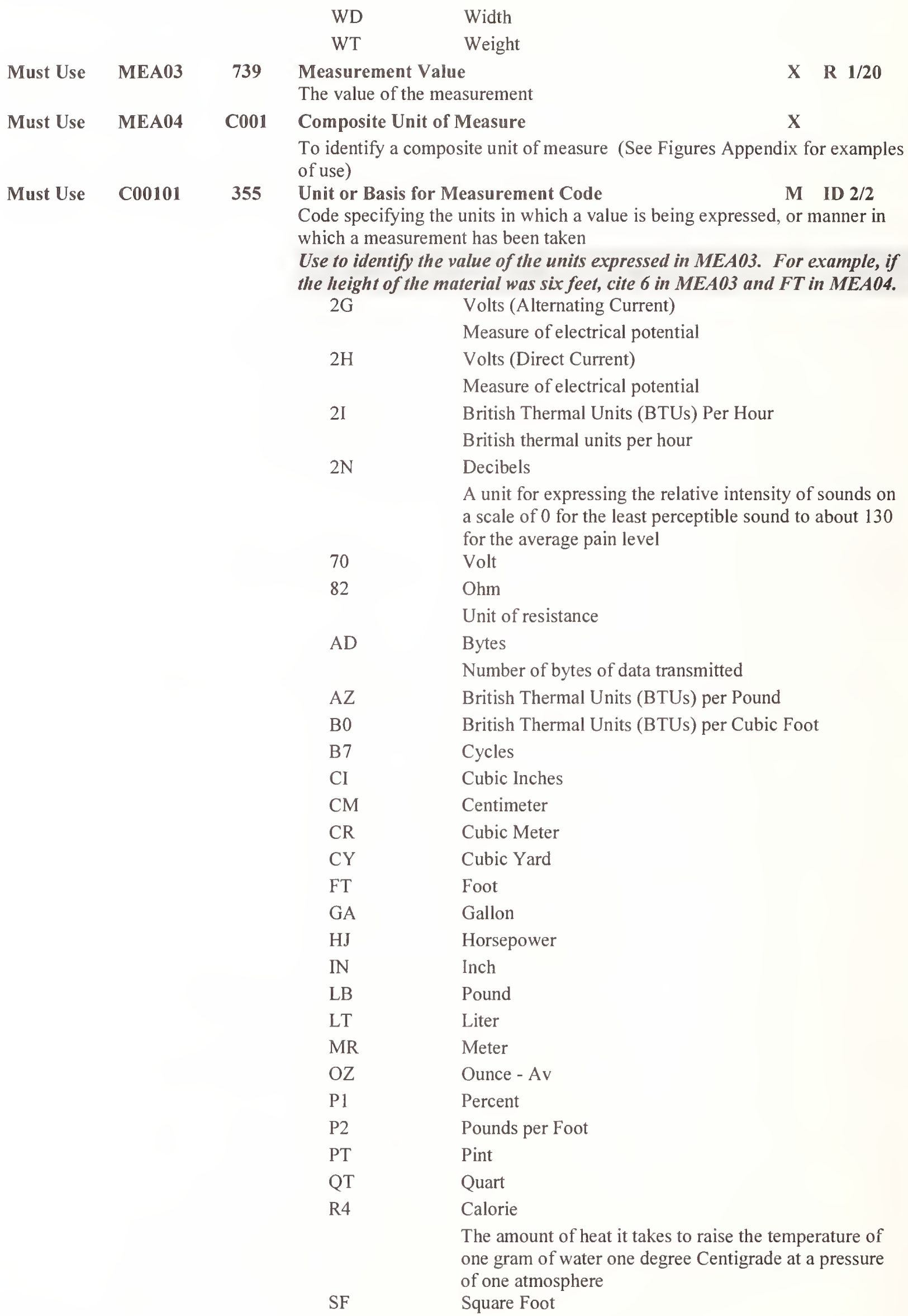




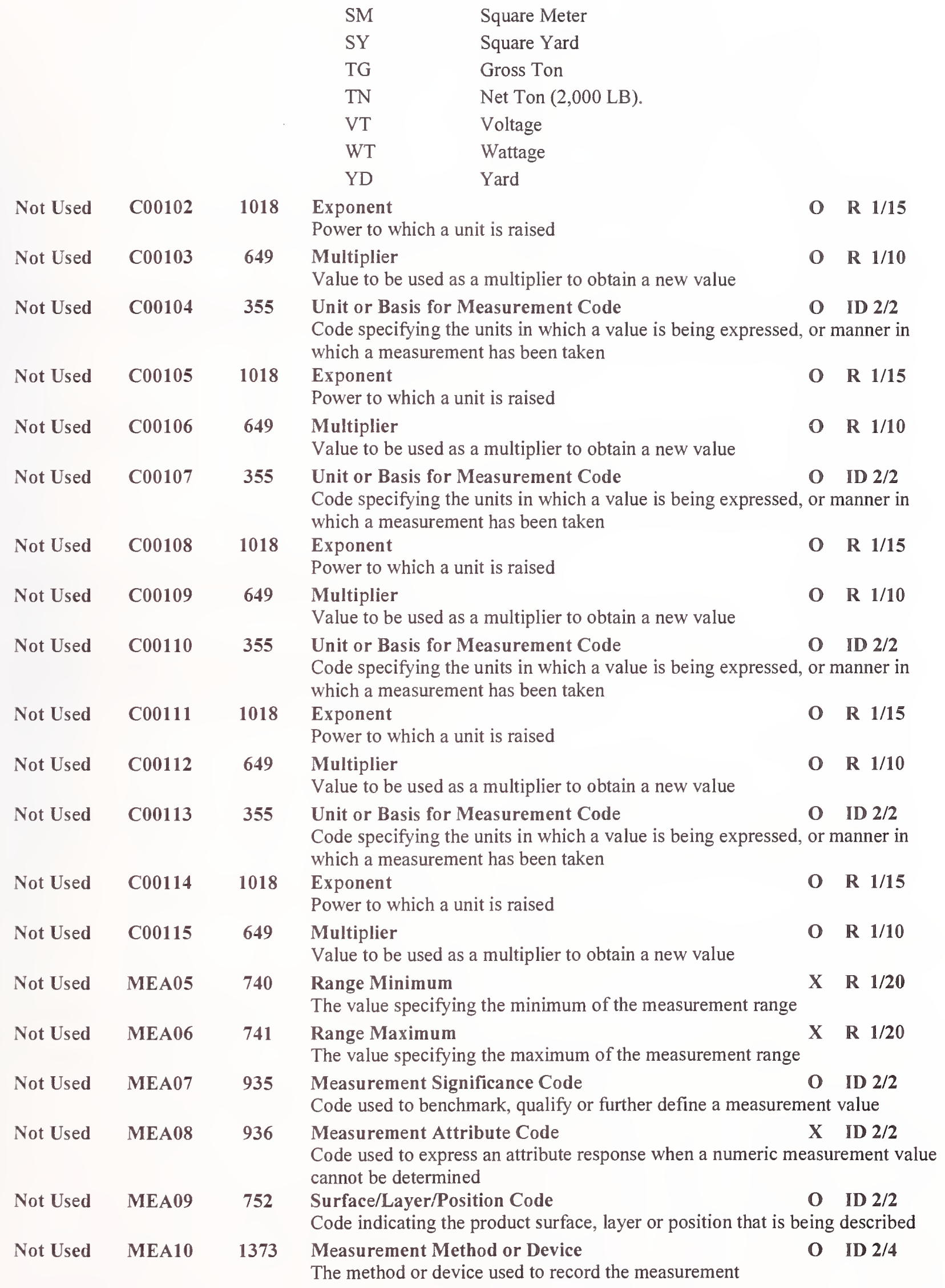




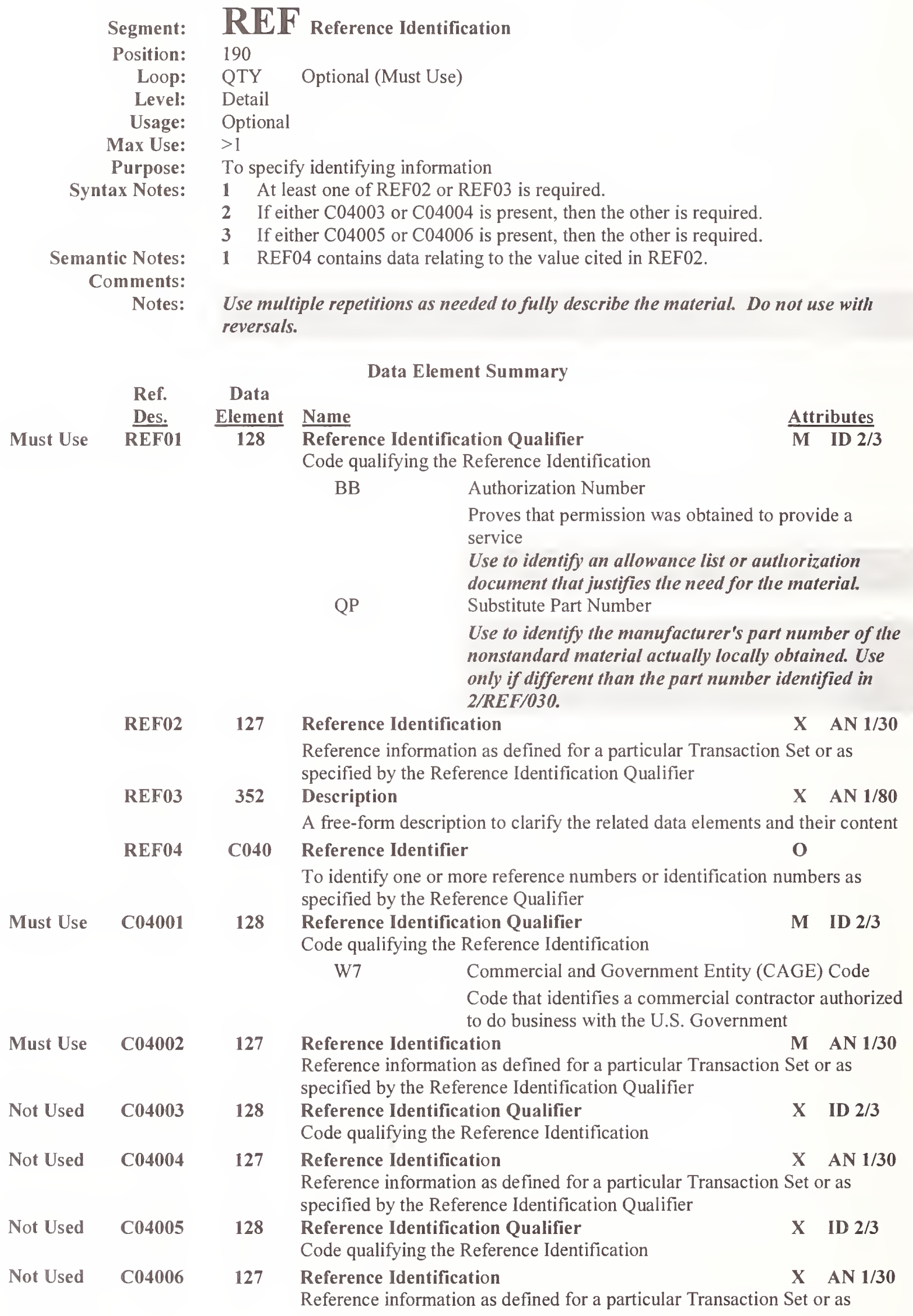


867D - Product Transfer and Resale Report (Demand)

specified by the Reference Identification Qualifier 


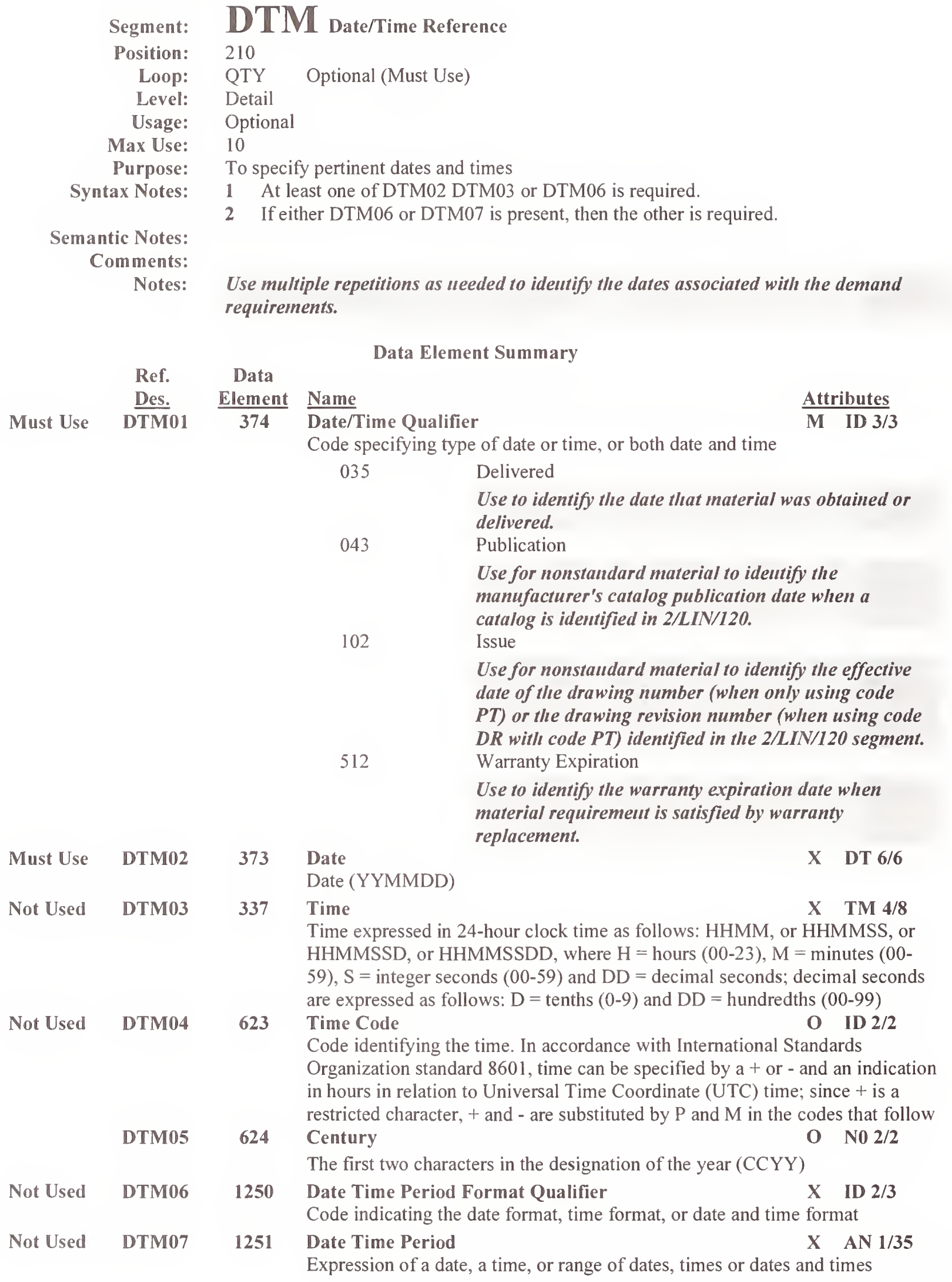




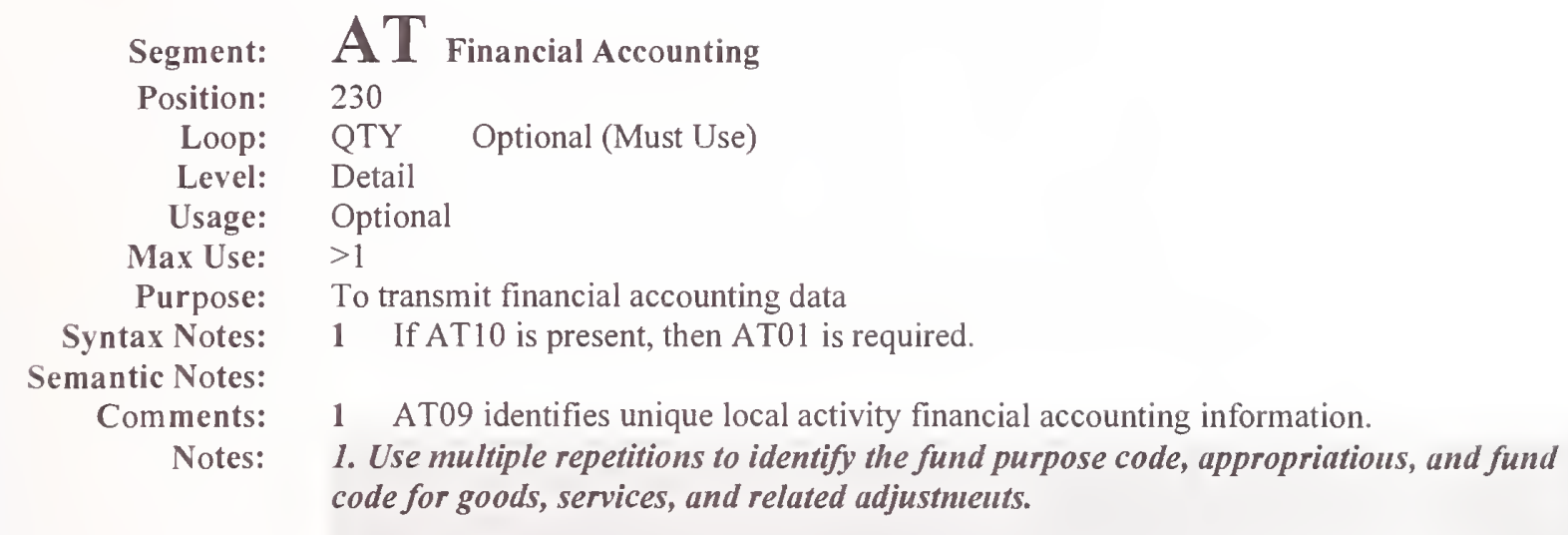

2. DLMS users see the Accounting Classification Appendix for AT02, AT07 aud AT09.

Ref. Data

Must Use $\quad \frac{\text { Des. }}{\text { AT01 }}$

AT02

AT03

1283

$\frac{\text { Element }}{1271}$

1282 Treasury Symbol Number

Number identifying a departme appropriation limit for a stand Use to identify the basic appropriation number.

Industry Code

Code indicating a code from a specific industry code list

Attributes

$\mathrm{X} \quad$ AN $1 / 30$

O AN 7/21

Budget Activity Number

O AN 1/16

Number identifying an administrative subdivision of funds against which a transaction is to be charged for a standard accounting classification coding structure

Use to identify the fund code.

Not Used AT04

1284

Object Class Number

O AN 3/12

Number identifying the nature of the goods or services acquired and a specific office or organization using resources for a standard accounting classification coding structure

Not Used AT05

Not Used

AT06

AT07

Not Used

AT08

AT09

Must Use
1285

1286

Reimbursable Source Number

O AN 1/3

Number identifying the source of an appropriation or fund reimbursement for a standard accounting classification coding structure

Transaction Reference Number

O AN 4/20

Number identifying an original request for goods and services to the matching financial transaction for a standard accounting classification coding structure

1287 Accountable Station Number

O AN 3/8

Number identifying an office responsible for entering a financial transaction into the applicable accounting system for a standard accounting classification coding structure

Use AT07 to ideutify the Authorized Accounting Activity (AAA)/Accounting Disbursing Station Number (ADSN)/Fiscal Station Number (FSN).

Paying Station Number

O AN 8/14

Number identifying an office responsible for making a payment or collection and the corresponding voucher number under which the action was taken for a standard accounting classification coding structure

Description

O AN $1 / 80$

A free-form description to clarify the related data elements and their content

Cite supplemental accounting classification data.

Code List Qualifier Code

Code identifying a specific industry code list 
867D - Product Transfer and Resale Report (Demand) 


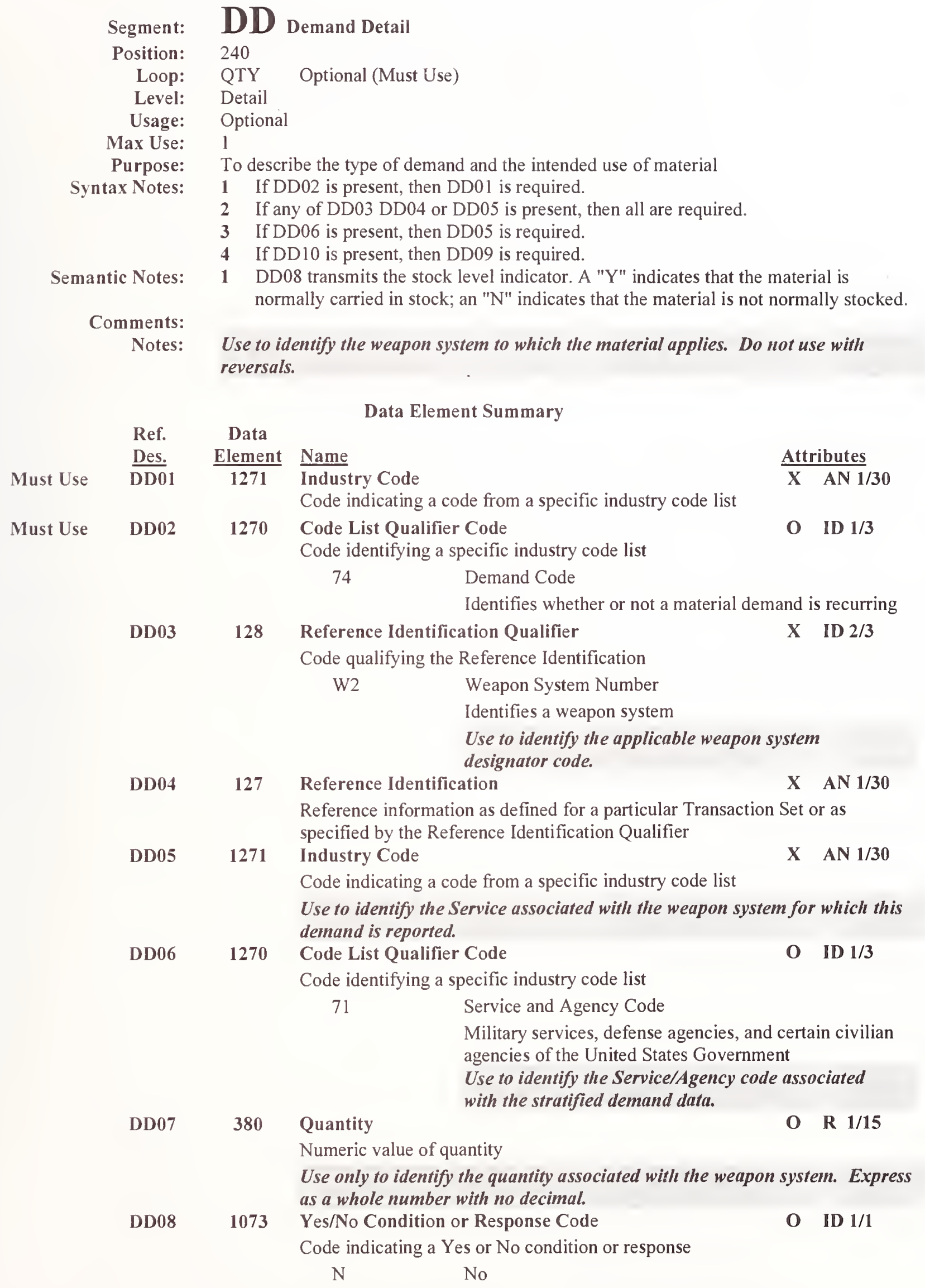


867D - Product Transfer and Resale Report (Demand)

Y Yes

\begin{tabular}{|c|c|c|c|c|c|}
\hline Not Used & DD09 & 1271 & Industry Code & $\mathrm{X}$ & AN 1/30 \\
\hline & & & Code indicating a code from a specific industry code list & & \\
\hline Not Used & DD10 & 1270 & $\begin{array}{l}\text { Code List Qualifier Code } \\
\text { Code identifying a specific industry code list }\end{array}$ & $\mathbf{O}$ & ID $1 / 3$ \\
\hline
\end{tabular}




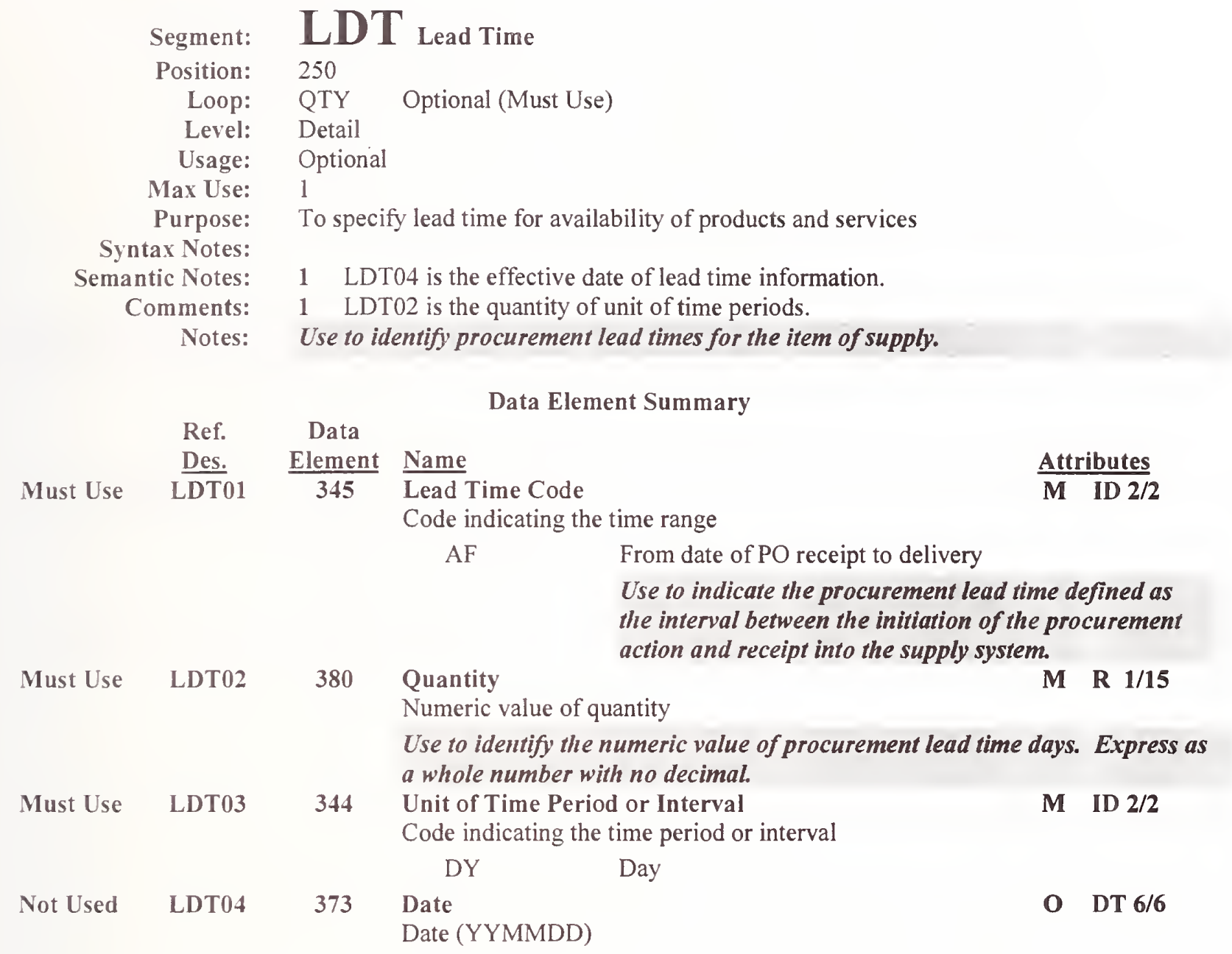




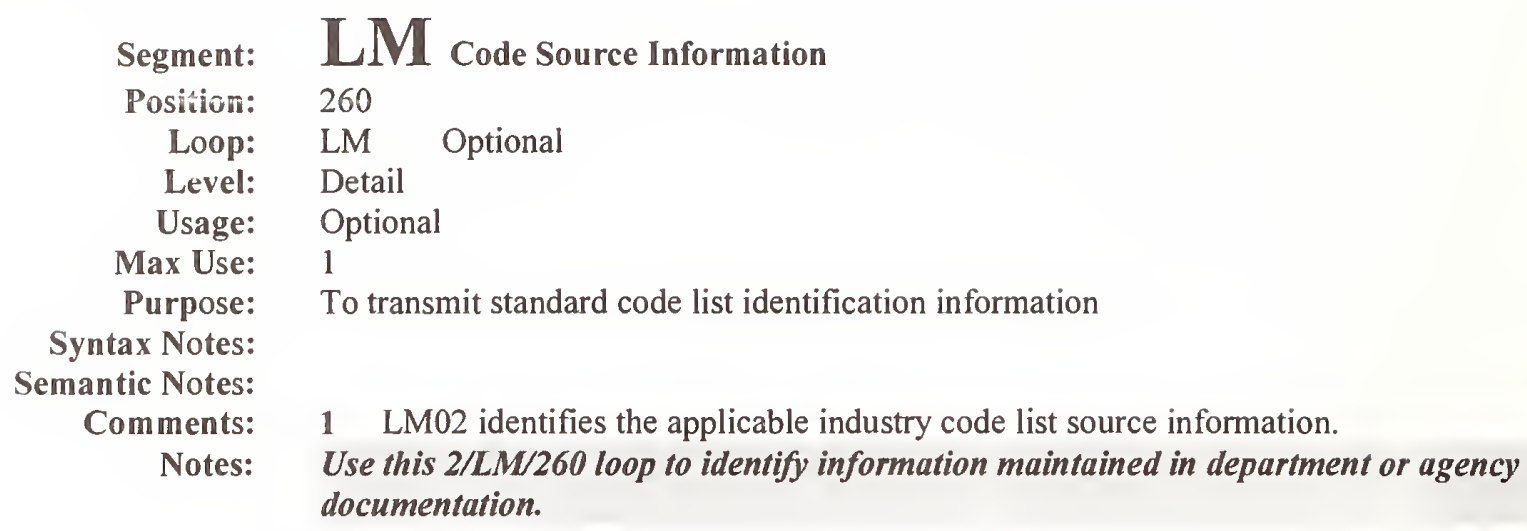

Must Use LM01 559

Agency Qualifier Code

Attributes

Not Used LM02
Code identifying the agency assigning the code values DF Department of Defense (DoD)

M ID 2/2

O AN 1/15

A reference that indicates the table or text maintained by the Source Qualifier 


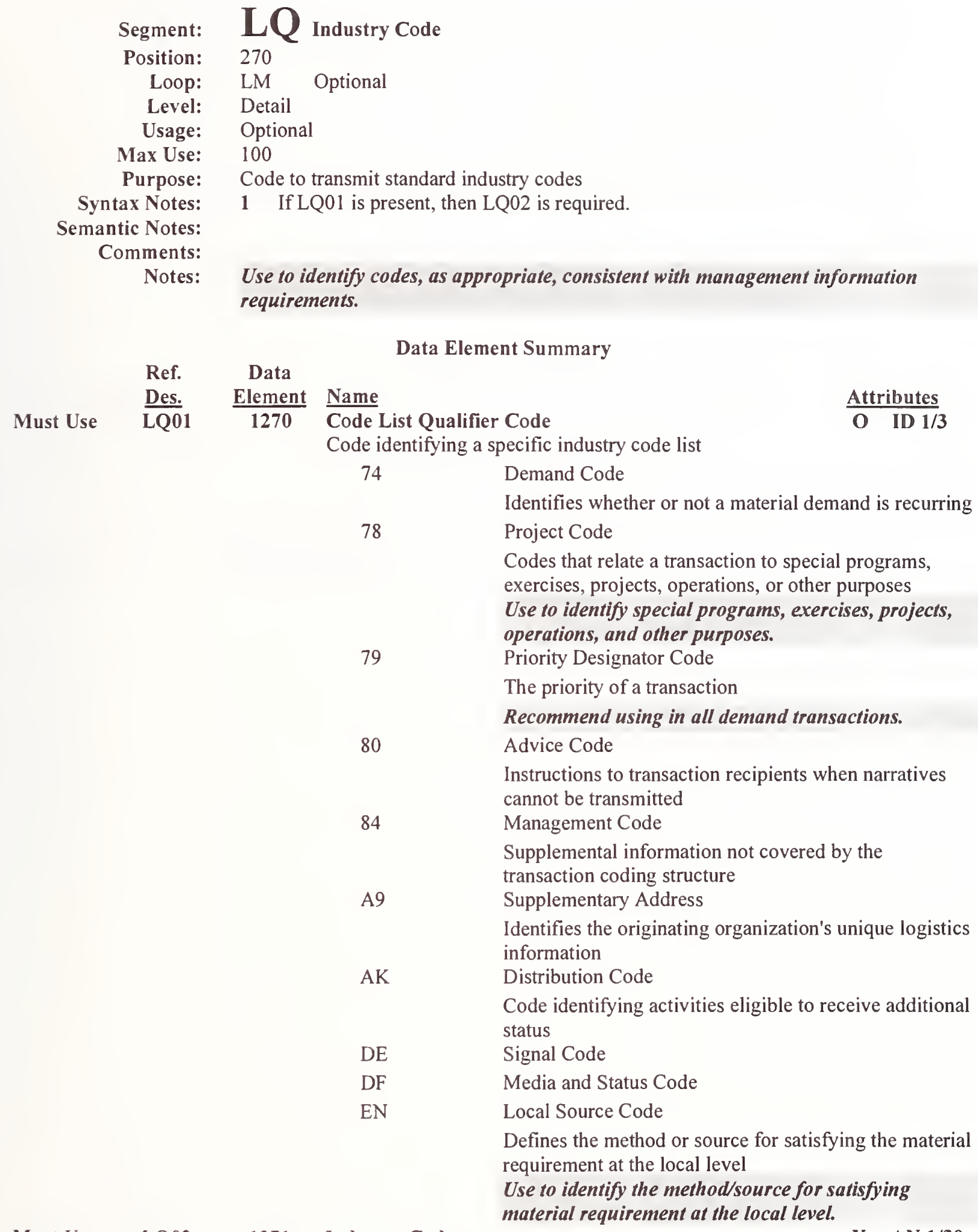

X AN 1/30 


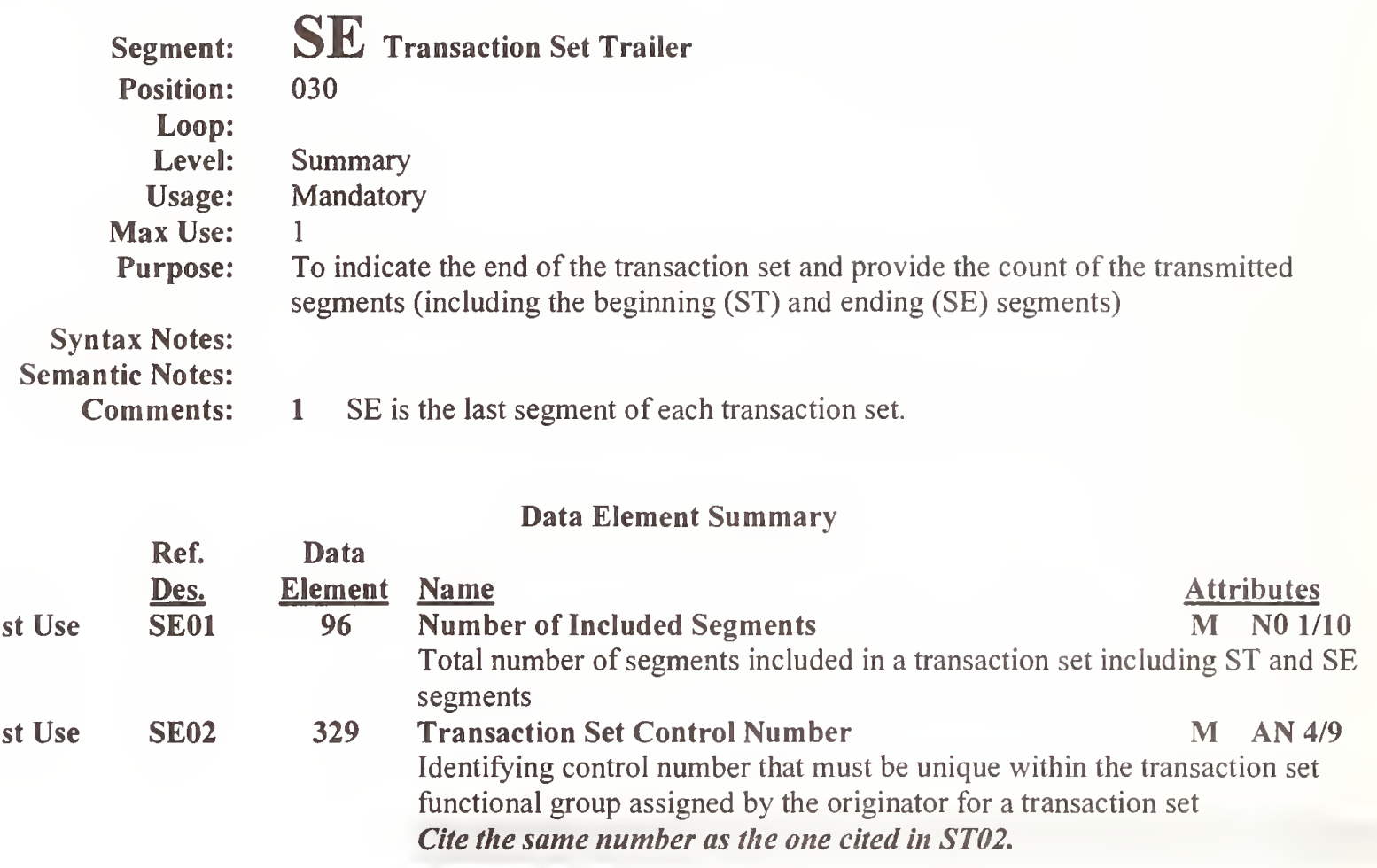




\section{.}





\section{NIST Technical Publications}

\section{Periodical}

Journal of Research of the National Institute of Standards and Technology-Reports NIST research and development in those disciplines of the physical and engineering sciences in which the Institute is active. These include physics, chemistry, engineering, mathematics, and computer sciences. Papers cover a broad range of subjects, with major emphasis on measurement methodology and the basic technology underlying standardization. Also included from time to time are survey articles on topics closely related to the Institute's technical and scientific programs. Issued six times a year.

\section{Nonperiodicals}

Monographs-Major contributions to the technical literature on various subjects related to the Institute's scientific and technical activities.

Handbooks - Recommended codes of engineering and industrial practice (including safety codes) developed in cooperation with interested industries, professional organizations, and regulatory bodies.

Special Publications - Include proceedings of conferences sponsored by NIST, NIST annual reports, and other special publications appropriate to this grouping such as wall charts, pocket cards, and bibliographies.

National Standard Reference Data Series-Provides quantitative data on the physical and chemical properties of materials, compiled from the world's literature and critically evaluated. Developed under a worldwide program coordinated by NIST under the authority of the National Standard Data Act (Public Law 90-396). NOTE: The Journal of Physical and Chemical Reference Data (JPCRD) is published bimonthly for NIST by the American Chemical Society (ACS) and the American Institute of Physics (AIP). Subscriptions, reprints, and supplements are available from ACS, 1155 Sixteenth St., NW, Washington, DC 20056.

Building Science Series-Disseminates technical information developed at the Institute on building materials, components, systems, and whole structures. The series presents research results, test methods, and performance criteria related to the structural and environmental functions and the durability and safety characteristics of building elements and systems.

Technical Notes-Studies or reports which are complete in themselves but restrictive in their treatment of a subject. Analogous to monographs but not so comprehensive in scope or definitive in treatment of the subject area. Often serve as a vehicle for final reports of work performed at NIST under the sponsorship of other government agencies.

Voluntary Product Standards-Developed under procedures published by the Department of Commerce in Part 10, Title 15, of the Code of Federal Regulations. The standards establish nationally recognized requirements for products, and provide all concerned interests with a basis for common understanding of the characteristics of the products. NIST administers this program in support of the efforts of private-sector standardizing organizations.

Order the following NIST publications - FIPS and NISTIRs - from the National Technical Information Service, Springfield, VA 22161.

Federal Information Processing Standards Publications (FIPS PUB)-Publications in this series collectively constitute the Federal Information Processing Standards Register. The Register serves as the official source of information in the Federal Government regarding standards issued by NIST pursuant to the Federal Property and Administrative Services Act of 1949 as amended, Public Law 89-306 (79 Stat. 1127), and as implemented by Executive Order 11717 (38 FR 12315, dated May 11, 1973) and Part 6 of Title 15 CFR (Code of Federal Regulations).

NIST Interagency or Internal Reports (NISTIR)-The series includes interim or final reports on work performed by NIST for outside sponsors (both government and nongovernment). In general, initial distribution is handled by the sponsor; public distribution is handled by sales through the National Technical Information Service, Springfield, VA 22161, in hard copy, electronic media, or microfiche form. NISTIR's may also report results of NIST projects of transitory or limited interest, including those that will be published subsequently in more comprehensive form. 


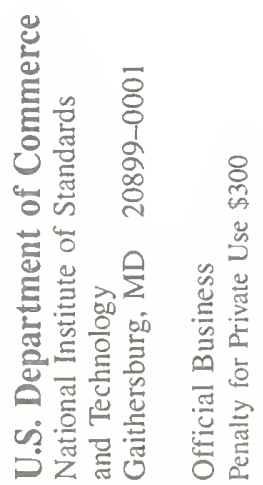

